\title{
The Science of Team Science: Exploring Principal Investigator Leadership Style and Team Collaboration Satisfaction
}

\author{
Stephenie K. Kennedy \\ West Virginia University
}

Follow this and additional works at: https://researchrepository.wvu.edu/etd

\section{Recommended Citation}

Kennedy, Stephenie K., "The Science of Team Science: Exploring Principal Investigator Leadership Style and Team Collaboration Satisfaction" (2013). Graduate Theses, Dissertations, and Problem Reports. 490. https://researchrepository.wvu.edu/etd/490

This Dissertation is protected by copyright and/or related rights. It has been brought to you by the The Research Repository @ WVU with permission from the rights-holder(s). You are free to use this Dissertation in any way that is permitted by the copyright and related rights legislation that applies to your use. For other uses you must obtain permission from the rights-holder(s) directly, unless additional rights are indicated by a Creative Commons license in the record and/ or on the work itself. This Dissertation has been accepted for inclusion in WVU Graduate Theses, Dissertations, and Problem Reports collection by an authorized administrator of The Research Repository @ WVU.

For more information, please contact researchrepository@mail.wvu.edu. 
The Science of Team Science: Exploring Principal Investigator Leadership Style and Team Collaboration Satisfaction

\author{
Stephenie K. Kennedy
}

Dissertation submitted to the College of Education and Human Services

at West Virginia University

in partial fulfillment of the requirements for the degree of

Doctor of Education in

Educational Leadership Studies

\author{
Reagan Curtis, Ph.D. , Chair \\ Geri Dino, Ph.D. \\ Margaret Glenn, Ed.D. \\ Ernest Goeres, Ph. D. \\ Nathan Sorber, Ph.D.
}

Department of Advanced Educational Studies

Morgantown, West Virginia

2013

Keywords: Leadership, Collaboration, Interdisciplinary research teams, Science of team science Copyright 2013 Stepehenie K. Kennedy 


\begin{abstract}
The Science of Team Science: Exploring Principal Investigator Leadership Style and Team Collaboration Satisfaction
\end{abstract}

Stephenie K. Kennedy

This study examined the relationship between the leadership style of principal investigators (PIs) of interdisciplinary research teams at academic health science centers and the collaboration satisfaction of their team members. Two stage sampling was used. One hundred NIH-funded principal investigators at eight regional health science centers completed a team identification form, identifying their teams as interdisciplinary and providing the names and emails of team members. An online survey instrument that included a basic demographic questionnaire, the Bolman and Deal Leadership (Others) Survey, and the Collaboration and Transdisciplinary Integration Survey was then sent to team members. The sample used for analysis included 170 individuals from 38 teams at 7 institutions. Team members identified that the PIs used all of the frames, but were more likely to use the human resource and structural frames. The pattern of frame use resulted in the identification that PIs were more likely to adopt a multi-frame leadership style rather than the no, single, or paired styles. Nearly 53 percent of teams identified that their satisfaction with collaboration was good to excellent, but the areas of team meeting productivity and conflict resolution were identified as potential areas of improvement. An analysis of variance was completed and demonstrated that there was a significant difference in collaboration satisfaction; the political frame differed significantly from both the symbolic and human resource frames. Additionally, team members' reports were significantly different between leaders using the multi-framed style and the no frame style. The effect size for this sample was small and indicated that approximately five percent of the variance could be explained by leadership. Most teams were composed of six to ten members and led by experienced PIs. The gender of the PIs was $58 \%$ male and $42 \%$ female. 


\section{Running Head: PI LEADERSHIP STYLE AND COLLABORATION}

\section{Acknowledgements}

I want to express my thanks to the members of my dissertation committee for their guidance, probing questions, and kindness during this educational journey. The positive comments and thoughtful dialogue allowed me to learn throughout the process. Much appreciation is extended to Dr. Reagan Curtis for agreeing to chair this committee, provide methodological support, and assist in the completion of the document.

I also want to thank my mentors, Dr. Scot Remick, Dr. Laura Gibson, Pamela Brown, and Lisa Shepard for their support and encouragement along the way. I also wish to acknowledge my professional colleagues at West Virginia University, Pennsylvania State University, Ohio State University, Virginia Tech, and the University of Kentucky for their kind words and motivation.

Finally, I want to acknowledge my family and friends for keeping me grounded and focused during the difficult times. I want to express my gratitude to my parents, grandparents, and Aunt "Bert" for encouraging me at a young age to set goals, challenge myself, and apply the gifts I was given. Many thanks are also extended to my sister for always keeping me humble, to my long distance lifeline, Chris, for sharing $25+$ years of friendship and teaching me that a good laugh is healing, and to the Sunday night book club for reminding me that literature enhances our lives and there is always time for a good book. Lastly, and most importantly, my heartfelt thanks go to the "home team" of Julie, Josie, and Jordan whose love, patience, prodding, laughter, and support ensured that this research was completed and my sanity maintained. I am blessed, both personally and professionally, with people in my life who believe in me and the work I do; I am forever grateful. 


\section{Table of Contents}

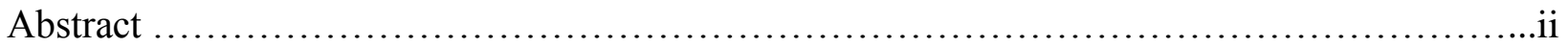

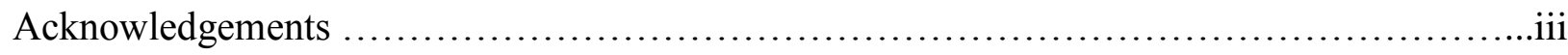



List of Tables ....................................................................... vii

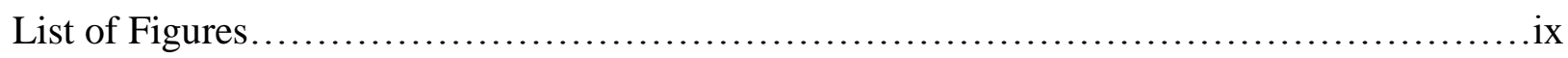

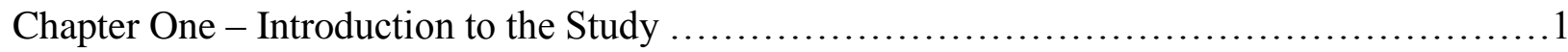



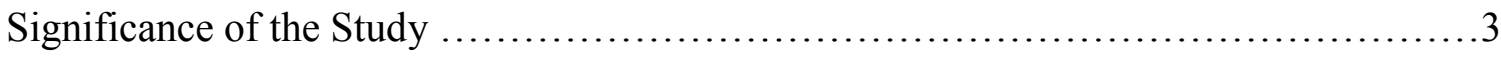

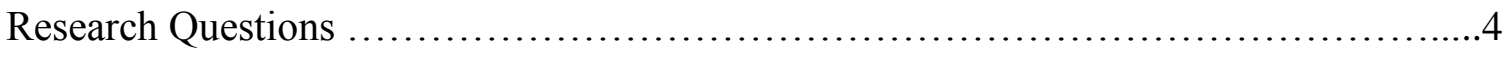

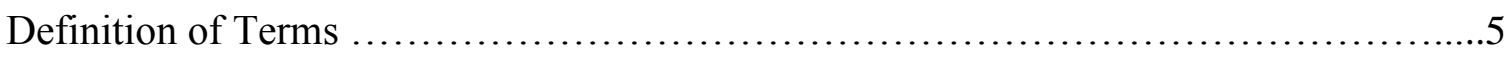

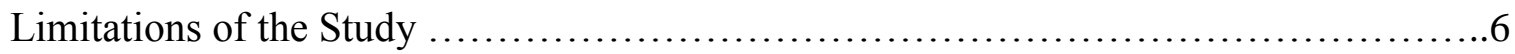

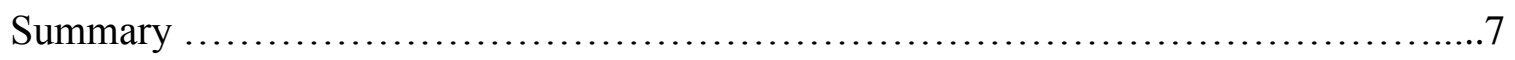

Chapter Two - Literature Review ................................................. 9

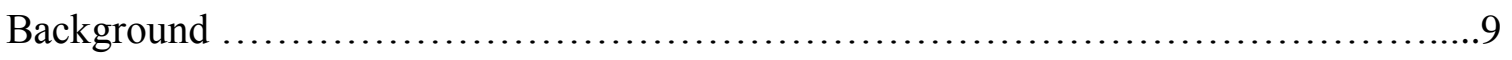

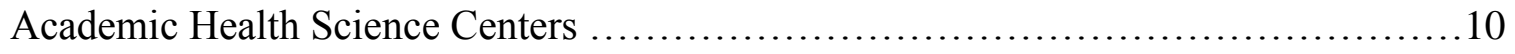

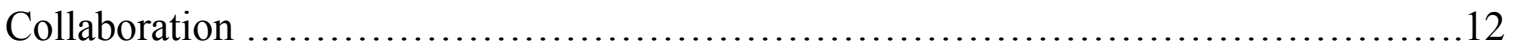

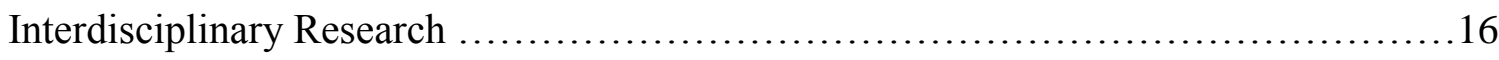

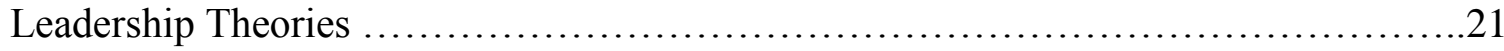

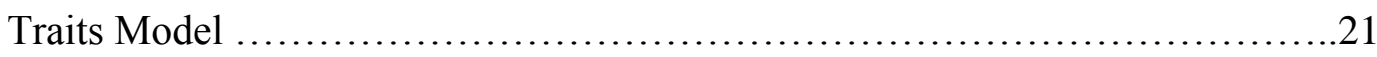

Behavioral Model ....................................................22

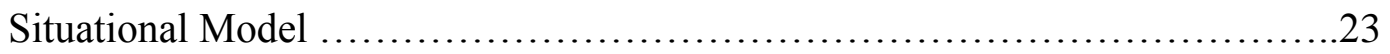

Functional Model ...................................................25 
Running Head: PI LEADERSHIP STYLE AND COLLABORATION

Transformational Model ...............................................25

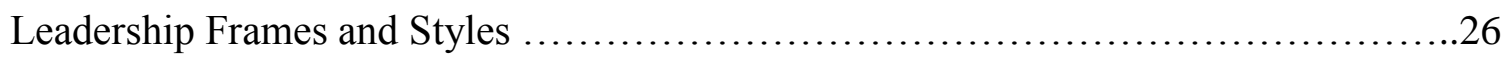

Measurement of Leadership and Collaboration Satisfaction ........................29

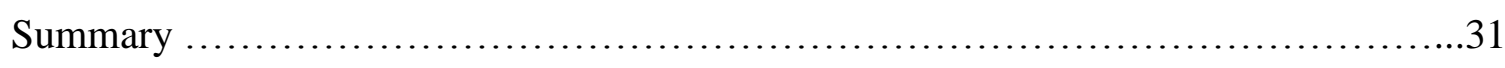

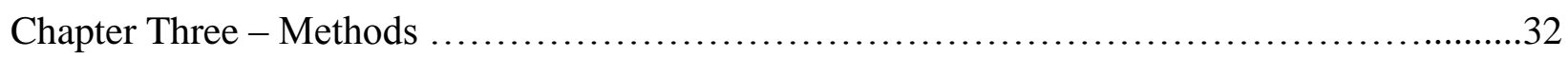

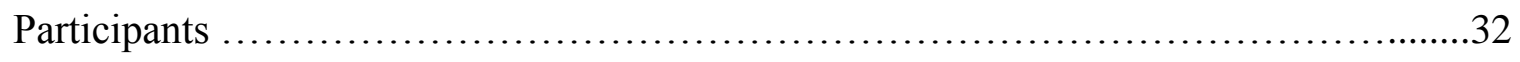



Survey Responses ....................................................... 33

Respondent Data ..................................................34

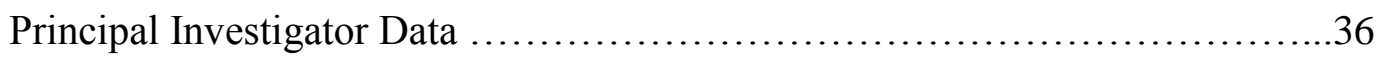

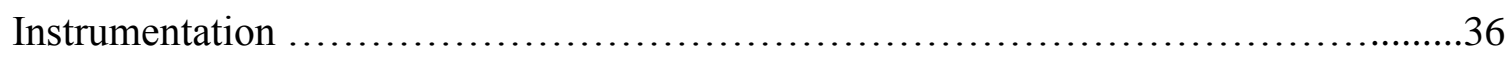

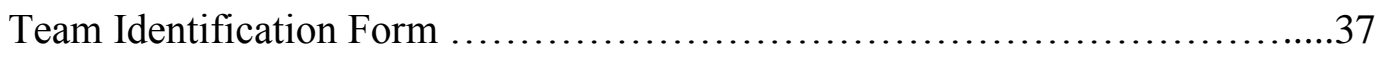

Demographic Questionnaire ..........................................37

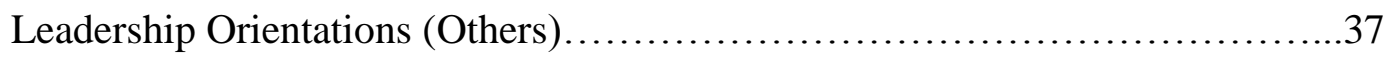

Collaboration and Transdisciplinary Integration Survey ......................39

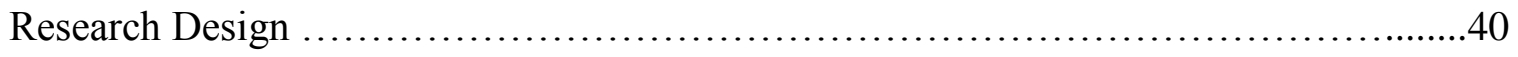

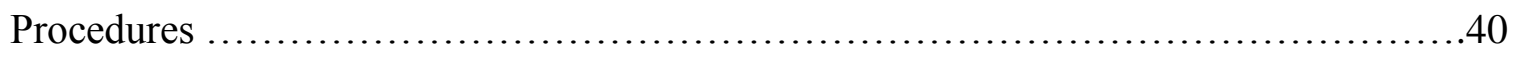

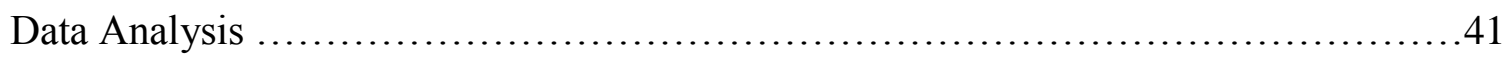

Research Question One...............................................42

Research Question Two ...........................................42

Research Question Three.............................................42

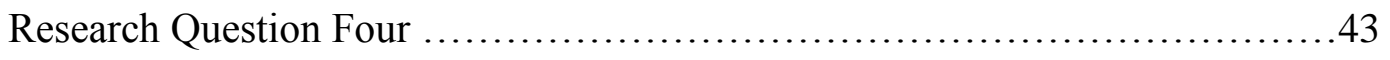

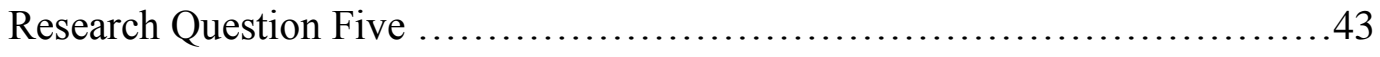


Running Head: PI LEADERSHIP STYLE AND COLLABORATION

Approach to Dealing with Missing Values ....................................43



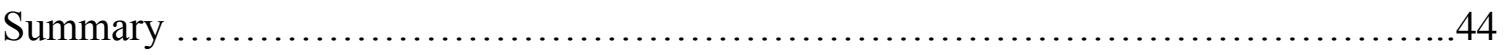

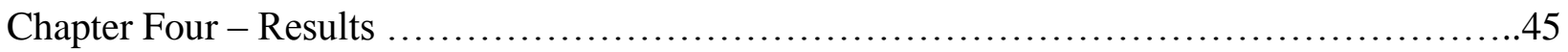



Research Question One .............................................45

Research Question Two ............................................48

Research Question Three ..............................................50

Research Question Four ...........................................51

Research Question Five ............................................53

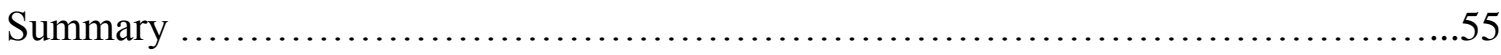

Chapter Five - Conclusions and Recommendations ...................................59

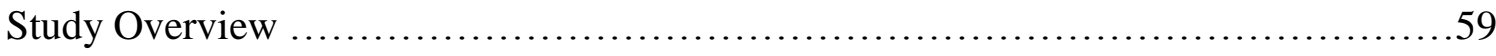

Discussion and Application of the Findings.......................................61

Research Question One ...............................................61

Research Question Two ............................................64

Research Question Three ..............................................67

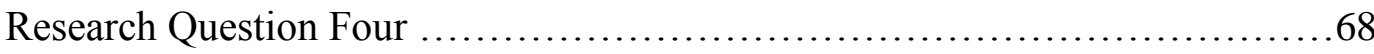

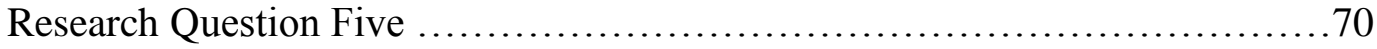

Incidental Finding .................................................... 71



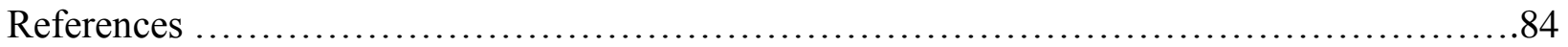


Running Head: PI LEADERSHIP STYLE AND COLLABORATION

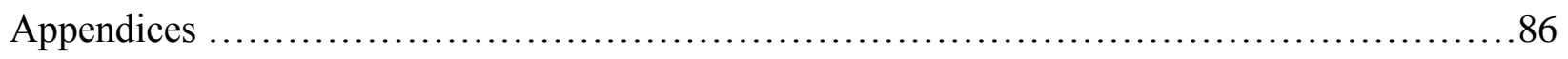

A. Permission to Use Table of Factors Facilitating and Constraining Transdisciplinary



B. Permission to Use Hersey and Blanchard's Four Quadrant Model of Situational

Leadership ....................................................... 87

C. Carnegie Classification: Research Universities (very high research activity) ........88

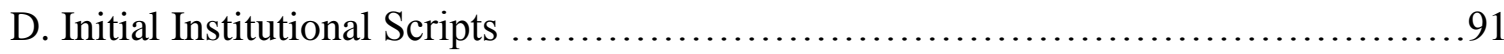

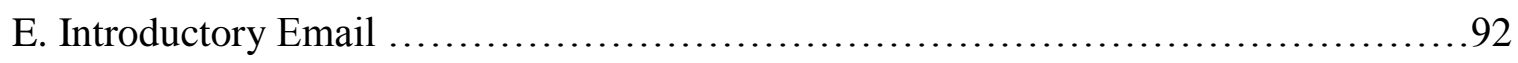

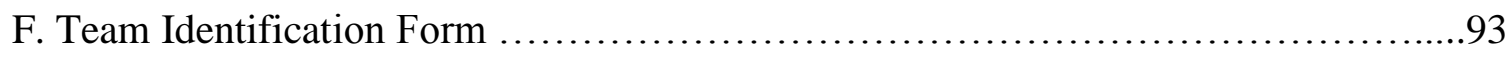

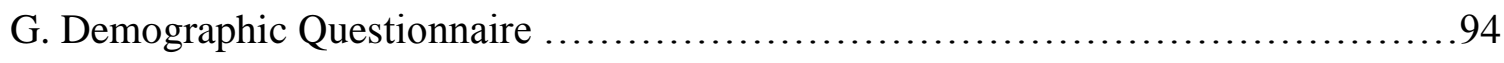

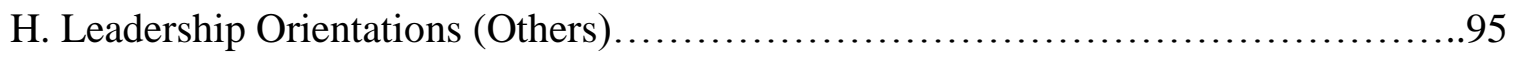

I. Collaboration and Transdisciplinary Integration Survey ......................... 98

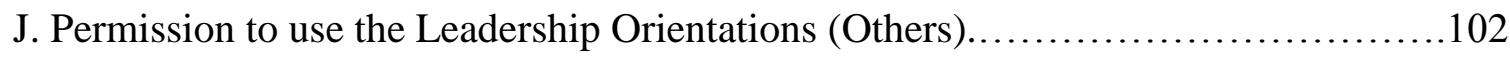

K. Permission to use the Collaboration and Transdisciplinary Integration Survey ......103 
Running Head: PI LEADERSHIP STYLE AND COLLABORATION

\section{List of Tables}

Table $1 \quad$ Perspectives on the Importance of Collaboration $\ldots \ldots \ldots \ldots \ldots \ldots \ldots \ldots \ldots \ldots \ldots \ldots$



Table 3 Factors Constraining Transdisciplinary Team Science $\ldots \ldots \ldots \ldots \ldots \ldots \ldots \ldots \ldots 17$

Table 4 Demographic Variables of Respondents ................................ 35

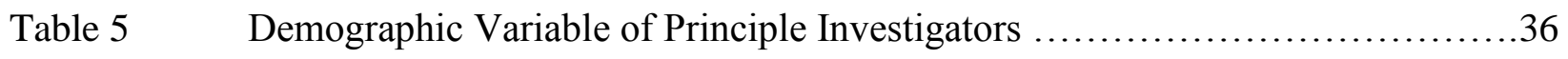

Table 6 Means and Standard Deviations of PI Leadership Frames Rated by Teams ......46

Table 7 Frequency Distribution for Frame Use by Principal Investigators ..............47

Table $8 \quad$ Frequency Distribution by Frame Pattern ................................48

Table 9 Frequency Distribution for Team Means on the Collaboration Satisfaction

Scale.............................................................49

Table 10 Difference in Collaboration Satisfaction by Category of Dominant Leadership

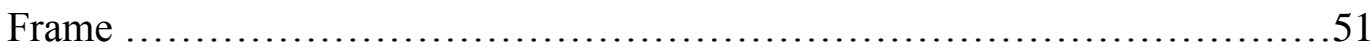

Table 11 Difference in Collaboration Satisfaction by Category of Leadership Style ......53

Table 12 Gender * Style Crosstabulation .....................................54

Table 13 Time as a Principal Investigator * Style Crosstabulation ....................54

Table 14 Size of the Research Team * Style Crosstabulation ..........................55 
Running Head: PI LEADERSHIP STYLE AND COLLABORATION

\section{List of Figures}

Figure 1 Evolution of identified areas of research in the emerging field of the science of team science........................................................... 20

Figure 2 Hersey and Blanchard's Situational Leadership Theory.....................24

Figure 3 Relationship of Gray's Tasks to Bolman and Deal's Frames ...................29

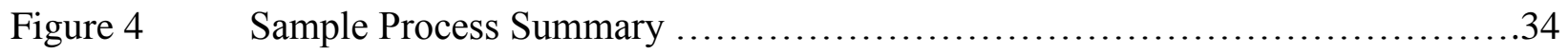

Figure 5 Frequency Distribution for Item Responses on the Collaboration Satisfaction

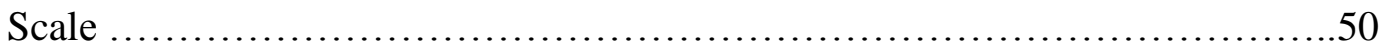




\section{Running Head: PI LEADERSHIP STYLE AND COLLABORATION}

\section{Chapter 1}

\section{Introduction to the Study}

Institutions of higher education have historically been viewed as distinct from the real world, separated both figuratively and literally, often times by a wall or barrier. As the research ideal became entrenched in the American academy, there was increased emphasis placed on specialization and refinement within disciplines. In the sciences one could even identify that the drive was toward hyper-specialization, further isolating even those within the walls of the institution. Bellah (1991) stated that "the research university, the cathedral of learning ... far from becoming a new community that would bring coherence out of chaos, became instead congeries of faculty and students, each pursuing their own ends, integrated not by any shared vision..." (p. 155). Scientists were, and continue to be, prepared as independent thinkers pursuing new knowledge in their own laboratories, engaging with those from their discipline, and speaking their own language. Fox and Faver (1984) argued that "scientists are expected to select problems freely, to exercise independent judgment in methods and techniques, and to evaluate without constraint the validity of their own results and those of others" (p. 347). This situation persevered and is evident in today's institutions (Bozeman \& Boardman, 2004, 2007; Siegel, Waldman, Atwater, \& Link, 2003).

As the research mission of colleges and universities grows and changes, faculty members are asked to descend from their departmental ivory towers, leaving behind research silos, to work collaboratively with fellow scientists from various disciplines. Jeffrey (2003) stated, "Real-world problems do not come in disciplinary-shaped boxes" (p.539) and current research requires transcending the single discipline approach (Fiore, 2008; Illman, 2007; Stokols, Hall, Taylor, \& Moser, 2008). The pressure for increased research funding and innovative approaches requires 


\section{Running Head: PI LEADERSHIP STYLE AND COLLABORATION}

the use of interdisciplinary teams. The National Institutes of Health (grants.nih.gov)

acknowledge that new breakthroughs depend on the work of integrated teams of scientists and identify that this type of work is inherently difficult. A number of funding agencies, particularly federal agencies, are now requiring interdisciplinary collaboration for funded projects; the inclusion of funding announcements tailored to interdisciplinarity demonstrates expanding investment in this type of research.

Collaboration brings scientists together to work on a mutually defined design that typically results in a funding application, and if funded, a completed project with publications. Successful collaboration requires communication, commitment, respect, and flexibility (Borrego \& Newswander, 2010; Oandasan et al., 2006; Russell \& Flynn, 2000). Researchers must step outside their comfort zones to attain these necessary components and have an identified leader to govern the process (Fox \& Faver, 1984; Jeffrey, 2003).

Typically the principal investigator (PI) serves as the leader of a research team. The PI must manage the team because without such leadership the resultant role confusion and ambiguity lead to the group's demise. In Reframing Organizations, Artistry, Choice and Leadership, Bolman and Deal (2003) identify how maintenance of core beliefs and use of a multi-frame approach improves leadership and leads to organizational efficiency. They explore the structural, human resource, political, and symbolic frames and demonstrate how the use of multiple frames serves as "maps that aid navigation and tools for solving problems and getting things done" (p.18). The structural frame relates to strategic planning, goal setting, policy making, and fact finding in an organization. In comparison, the human resource frame focuses on human needs and how the organization addresses and meets those needs. The political frame centers on power, conflict and bargaining, while the symbolic frame emphasizes the maintenance 
Running Head: PI LEADERSHIP STYLE AND COLLABORATION

of institutional culture, tradition, and values. Most leaders rely on a dominant frame which can be identified by their followers (Bensimon, 1989; Bolman \& Deal, 1991).

\section{Statement of the Problem}

The science of team science is an emerging field and identifies that leadership is an important attribute, but to date no empirical studies have been completed in this area. This study aims to identify the leadership styles of PIs, to measure the satisfaction levels of members of collaborative research teams, and to discern if there is a difference in satisfaction related to the leadership style of the PI in interdisciplinary research teams in academic health science centers.

\section{Significance of the Study}

The area of team science, that is, investigations that study how research teams interact and the significance of this, is an emerging field of study. Robert Croyle (2008), an official at the National Cancer Institute, advocates for further development of the science of team science. A group of like-minded researchers agree and in April 2010 organized the first international science of team science conference in Chicago, IL with the goal of bringing together scientists from a variety of backgrounds to identify the key concepts related to this new field of study. Participants completed a concept mapping activity that categorized the following research directions for team science: definitions and models; disciplinary dynamics; structure and context for teams; institutional support and professional development; management and organization; and characteristics and dynamics of teams (Falk-Krzesinski et al., 2010). This group continues its work today and recently held their fourth conference (http://www.scienceofteamscience.org/). To date no one has empirically categorized leadership of interdisciplinary research teams. This study examines the role of leadership using the leadership frames defined by Bolman and Deal and further measures collaboration satisfaction and its potential relationship to leadership style. 


\section{Running Head: PI LEADERSHIP STYLE AND COLLABORATION}

Increasing knowledge of the relationship of these components will result in a better understanding of the phenomena of coming together to create an organizational culture where collaboration is both encouraged and reinforced. Integrated teams working on real world problems are the gold standard for current research and there is a clear need for a scientific approach to evaluation and impact studies related to the work of these teams.

\section{Research Questions}

Research question 1. What are the leadership styles (as measured by the frames) of the principal investigators of interdisciplinary research teams?

Research question 2. What is the collaboration satisfaction of interdisciplinary research teams?

Research question 3. Is there a statistically significant difference in the collaboration satisfaction scores of research team members who have principal investigators with different dominant leadership frames (structural, human resource, political, and symbolic)?

Research question 4. Is there a statistically significant difference in the collaboration satisfaction of research team members who have principal investigators with different leadership styles (no, single, paired, or multi-framed)?

Research question 5. How does the leadership style of principal investigators vary by demographic variables of gender, length of time as principal investigator (less than 3 years, 4 to 5 years, and longer than 6 years), and the size of research team (the number of team members is less than 5, between 6 and 10, and greater than 11)? 
Running Head: PI LEADERSHIP STYLE AND COLLABORATION

\section{Definition of Terms}

Interdisciplinary research team. Rosenfield (1992) identified such a team as a group in which members from different fields, disciplines, or professions come together to conduct problem oriented research over extended periods of time. This may also be referred to as multidisciplinary, cross-disciplinary, or transdisciplinary research.

Collaboration. The process of individuals coming together to work on a defined problem; this process requires communication, commitment, respect, and flexibility.

Principal investigator. The lead scientist on a research team who oversees the scientific methodology; there may be other team members who take on various management activities during the course of the research.

Four leadership frames. According to Bolman and Deal (2003), frames are windows, lenses, or perspectives through which a leader views a situation and responds; there are four frames: structural, human resource, political, and symbolic.

Structural frame. The structural frame emphasizes efficiency, rationality, and legality. Leaders tend to be highly structured, setting goals and relying on policies and procedures to guide their work.

Human resource frame. The human resource frame promotes collegial relationships. Leaders view the organization as meeting the needs of the employee and see their role as creating a harmonious environment.

Political frame. The political frame emphasizes power, control, and bargaining. Leaders employing this frame see the organization as an ongoing arena of conflict and engage as diplomats in power plays, building coalitions, setting agendas, and focusing on trade-offs. 
Running Head: PI LEADERSHIP STYLE AND COLLABORATION

Symbolic frame. The symbolic frame relates to the culture of the organization. Leaders look to this shared meaning to provide direction, create a sense of shared purpose, and decrease uncertainty for organizational members. Use of this frame honors heroes, traditions, rituals, ceremonies, and symbols.

No frame leadership style. The principal investigators who have no dominant frame orientation are said to demonstrate a leadership style with no frame orientation.

Single frame leadership style. The principal investigators who rely on one, dominant frame are said to be single frame.

Paired frame leadership style. The principal investigators who rely on two of the four frames are identified as paired frame.

Multi-frame leadership style. Principal investigators who employ more than two frames are said to be multi-frame leaders.

Academic health science center. According to the Association of Academic Health Science Centers these institutions are accredited, degree-granting institutions of higher education that educate a wide range of health care professionals, provide patient care, and conduct broadbased research.

\section{Limitations of the Study}

1. In this study, there was no measurement of a team's readiness to engage in interdisciplinary team research.

2. In this study it is assumed that research team members are able to identify their satisfaction with the collaborative process and rate the leadership style of the PI.

3. This study centers on principal investigators in academic health science centers and this may limit the generalizability to other schools/colleges within institutions. 


\section{Running Head: PI LEADERSHIP STYLE AND COLLABORATION}

4. This is a regional study and this may limit the generalizability to other institutions.

5. This study only measures the impact of the PI and does not take into account the leadership roles or duties assumed by other team members.

6. This study does not take into account the impact of institutional or team nesting; that is the influence of the institution on the team and/or the effect of the team on the individual.

7. The study sample included only NIH-funded interdisciplinary research teams and this may limit generalizability.

\section{Summary}

In modern universities, scientific research has tended to be uni-disciplinary, solitary, and independent, but as pressures for grant funding have increased, researchers have been forced to address the idea of working as collaborators to solve real world problems. This requires strong leadership and a shift in culture. As a result of the change in culture and increasing demands for interdisciplinary approaches, there is an emerging area of study, the science of team science. This research project contributes to the growing body of team science literature by exploring the contextual factors of collaboration satisfaction and leadership.

This chapter briefly introduces the concepts related to this study: team science, interdisciplinary research, collaboration, and leadership in academic health science centers. It also develops the problem statement, poses the research questions, describes the significance, defines terms, and identifies the limitations of the study. Chapter 2 presents a detailed literature review of collaboration, interdisciplinary research, and leadership. Chapter 3 describes the methodology utilized in this study and is organized into eight sections: participants, instrumentation, research design, procedure, data analysis, approach to missing values, 


\section{Running Head: PI LEADERSHIP STYLE AND COLLABORATION}

confidentiality, and a summary. Chapter 4 presents the results of the study and Chapter 5 summarizes the research, discusses the major findings, and explores the applications and opportunities for further research. 


\section{Chapter 2}

\section{Literature Review}

This chapter reviews the major literature related to collaboration, interdisciplinary research, and leadership. It is organized into such topics as background, academic health science centers, collaboration, interdisciplinary research, leadership theories, Bolman and Deal's (2003) four leadership frames, and the measurement of leadership and collaboration satisfaction. The chapter is designed to provide historical context, description and relevance of the organization to be studied, and an overview of the significant concepts that contribute to the study. These themes form the basis on which the methodology was developed.

\section{Background}

Over the decades the focus on research has increased as institutions of higher education, including health science centers, have been called upon to solve national, and even international problems (Kessel \& Rosenfield, 2008; Kezar, 2005). Bell (1982), United States Secretary of Education in the 1980s, believed that one of the five federal roles in higher education was strengthening the research base at universities (Clark, 1985). This belief seems in line with Tierney (2006) who wrote that following World War II, the federal government "developed a research infrastructure that was heavily geared toward investment in higher education" (p. 8). This shift and focus on research versus more classical learning began during the University Transformation Era dating from 1870-1944 (Cohen, 1998).

Prior to 1870 , professors traveled to Germany and were introduced to education in German universities. These institutions focused on the discovery of knowledge, not just the teaching of an already established body of information; the emphasis was on scientific inquiry, 
research, and publication (Lucas, 1994). The German research ideal became embedded in American higher education and as a result, disciplines became more focused and specialized. The increased focus on specialization and discipline-specific work influenced and changed the culture in modern universities, including health science centers.

\section{Academic Health Science Centers}

In the United States there are approximately 101 Academic Health Science Centers with membership in the national Association of Academic Health Centers (AAHC). These centers are dedicated to educating health care professionals from a number of disciplines, delivering patient care in state of the art facilities, and engaging in cutting edge research. According to the AAHC (www.aahcdc.org), these institutions of higher education include an allopathic or osteopathic school of medicine and at least one other health professions school. In many states, Academic Health Science Centers serve as the backbone of the health delivery system and are responsible for the majority of biomedical and health services research. The missions of these institutions center on education, service, patient care, and research.

The organization and leadership of these centers varies greatly from institution to institution, but most maintain close relationships with their parent university. Fifty-nine percent of these institutions are public and $41 \%$ private with most led by male physicians (Rubin \& Black, 2005). Seventy percent of leaders report directly to university presidents and many have external advisory boards that provide expertise regarding clinical care and basic and clinical research. Academic Health Science Centers are a microcosm of the greater university, generating large amounts of research funding and providing significant value to the academic institution.

Respondents to a 2004 survey, conducted by the Association of Academic Health Centers, identifies that staffing is a major concern in these institutions, including those needed to 
Running Head: PI LEADERSHIP STYLE AND COLLABORATION

carry out scientific research (Rubin \& Black, 2005). Most of the centers responding to the survey cite an increase in both funding and expenditures for research. According to the survey responses, the average non-reimbursed research expenditures equal \$11 million per institution. National Institutes of Health $(\mathrm{NIH})$ research dollars generated by each center range from less than $\$ 100,000$ to $\$ 262$ million. Additional grant funding comes from other federal agencies and foundations. As pressures mount and competition increases, researchers and institutional leaders must identify ways to stand above the competition. Forming collaborative, interdisciplinary teams provides one such avenue, but presents its own unique difficulties.

Intellectual property disputes, interdisciplinary collaboration, and the impact of Health Insurance Portability and Accountability Act (HIPAA) on clinical research pose some of the greatest challenges facing Vice Presidents of Research in Academic Health Centers (Wartman, 2007). In this same report Wartman includes a quote from Randolph Hall, $\mathrm{PhD}$ who identifies that collaboration leads to transformative technologies and treatments, but that of the "thousands of excellent researchers, only a small number are leaders - people who can pull together interdisciplinary programs, build teams, and encourage innovative collaboration" (p. 31). University researchers and NIH scientists examine the issues and research needs related to interdisciplinarity a special supplement of the American Journal of Preventive Medicine (2008) and an issue of the journal, Translational Behavioral Medicine (2012). These leaders summarize the problems facing academic health science centers and this research study aims to explore two of these topics: interdisciplinary collaboration and leadership. Increasing knowledge of the relationship of these components will result in a better understanding of the phenomena of coming together to create an organizational culture where collaboration is both encouraged and 
Running Head: PI LEADERSHIP STYLE AND COLLABORATION

reinforced. These academic entities, health science centers, provide a natural laboratory to explore interdisciplinary work, leadership, and collaboration.

\section{Collaboration}

By the end of the twentieth century scientists were challenged to change their way of doing things; many organizations and funding agencies began calling for a shift from the culture of specialization, independence, and isolation to one of collaboration. "Reshaping the Graduate Education of Scientists and Engineers" was released in 1995 by the National Academy of Science's Committee on Engineering and Public Policy Issues, and in 2000, the Institute of Medicine released a similar report; both documents cited the need to move away from discipline specific studies to those where scientists work across disciplines (Smedley \& Syme, 2000). The importance of collaboration is not readily understood or accepted by faculty in an academic environment where independence and individual achievement have been and continue to be rewarded and highly valued (Boardman \& Ponomariov, 2007; Glied, Bakken, Formicola, Gebbie, \& Larson, 2007; Siegal, Waldman, Atwater, \& Link, 2003). In many instances, tenure and promotion are tied to individual research and publication and as a result faculty members, especially those who are untenured, do not engage in interdisciplinary research (Aboelela et al., 2007; Braxton, Luckey, \& Helland, 2002; Bruhn, 2000; Feller, 2002; Golde \& Gallagher, 1999; Gumport, 1988; Hart \& Mars, 2009; Heberlein, 1988; Tobin, 2007). Table 1 highlights the importance of collaboration in the university setting (Russell \& Flynn, 2000). 
Table 1

Perspectives on the importance of collaboration

\section{Partnership}

Provides a source of new allies

Builds on strengths of all participants

Permits learning about multiple perspectives on various issues

Supports capacity building to address issues

Encourages budget support from constituents' arrangement

Goals

Allows participants to set better goals

Encourages understanding of other sectors' goals

Supports the provision of the best education for youth

Leads to improved problem solving through an interdisciplinary approach

\section{Outcomes}

Reorganizes power to get things done

Builds consensus leading to easier implementation

Leads to efficiencies

Helps communication both internally and externally

Furthers each partner's own agenda and the potential for influencing other partners' agendas

Collaboration is a broad concept that can be difficult to define. In its simplest form it is a bringing together of individuals to work in a mutually respectful manner on a joint project. It requires communication, commitment, mutual respect, and flexibility. For the purposes of this study, collaboration will be defined in terms of both the task and the manner in which members work together (Jeffery, 2003; Minnis, John-Steiner \& Weber, 1998; O’Connor, Rice, Peters, \& Veryzer, 2003; Russel \& Flynn, 2000). 


\section{Running Head: PI LEADERSHIP STYLE AND COLLABORATION}

The principals in a true collaboration represent complementary domains of expertise. As collaborators, they not only plan, decide, and act jointly, they also think together, combining independent conceptual schemes to create original frameworks. Also, in a true collaboration, there is commitment to shared resources, power, and talent; no individual's point of view dominates, authority for decision and action reside in the group, and work products reflect a blending of all participants' contributions (Kessel \& Rosenfield, 2008; Klein, 2008; Minnis, John-Steiner, \& Weber, 1998; Wood \& Gray, 1991).

In addition to the definition, Russell and Flynn (2000) worked to identify commonalities across collaborations. The researchers used a survey instrument they developed based on an earlier qualitative study that identified 26 factors related to effective collaboration. They surveyed authors who had contributed to a themed journal on collaboration and concluded that the six highest factors associated with effective collaboration were: willingness to listen to other partners; mutual respect; long-term commitment; frequent communication; flexibility in working together to set goals and implement strategies; and careful selection of partners. In addition to this quantitative measure, many qualitative studies have explored various components related to collaboration (Fox \& Faver, 1984; Hafernik, Messerschmitt, \& Vandrick, 1997; Jeffery, 2003; Landry, Traore, \& Godin, 1996).

Fox and Faver (1984) studied the motivations, benefits, and costs of collaboration for researchers. They completed in-depth, semi-structured interviews with social scientists $(\mathrm{N}=20)$ and concluded there were inherent benefits in the collaborative process, including opportunities to join resources and divide labor, alleviate academic isolation, sustain motivation through external commitments, and create interpersonal energy. In addition, this research identified some 


\section{Running Head: PI LEADERSHIP STYLE AND COLLABORATION}

disadvantages that they divided into process and outcome costs. Process costs included time for negotiation and exchange; expenses for telephone, copying, mail, and travel; and the personal, socio-emotional investment required in collaborative relationships. Outcome costs cited: possible delay or loss of project, problems of evaluation and allocation of credit for the project, and potential loss of quality.

In another qualitative study, Jeffery (2003) spent eight months observing the interactions and acting as an intermediary of a cross-disciplinary research team made up of a ten researchers from diverse fields. He studied the collaborative process and found that the following components all played a role in the effectiveness of the team: vocabulary, metaphor, story-lines, negotiation, process, understanding, utility, and knowledge integration. He identified that increased time working together and maintenance of a core group helped facilitate these components and lead to higher output. Finally, Landry, Traore, and Godin (1996) determined through surveys they developed that collaborative research does increase researcher productivity (completion of projects and publications). In this study ( $\mathrm{N}=1566$ of 9350), geographical closeness and the field of research also contributed to academic research productivity.

All of these studies identified merits associated with collaborative research, but tempered their conclusions with the reality of the time and resource commitment needed to make such endeavors successful. In addition Hafernik, Messerschmitt, and Vandrick (1997) outlined the benefits and difficulties associated with collaboration, discussed the obstacles generally encountered, and offered advice on making collaboration work by using their own experiences as examples. They stated that collaboration is most successful when deadlines are set and collaborators meet regularly. In addition, other recommendations for success included respecting each other, not getting one's ego too involved, being willing to give and receive criticism, not 
Running Head: PI LEADERSHIP STYLE AND COLLABORATION

worrying about an equal division of labor, being willing to study topics that are not of primary interest, and being committed to the process, even when challenges present themselves. Clearly the benefits of working collaboratively rest in a team finding balance and defining processes and outcomes.

\section{Interdisciplinary Research}

Over the last two decades as the general studies on collaboration were being completed, a focus on interdisciplinary team science grew in health research. Scientists began defining team science and studying variables that contribute to the successful blending of disciplines. Tables 2 and 3 identify the facilitating and constraining forces associated with interdisciplinary research endeavors (Kessel \& Rosenfield, 2008).

Table 2

Factors facilitating transdisciplinary team science

\begin{tabular}{|c|c|}
\hline Factor & Facilitating \\
\hline Focus on major problems & $\begin{array}{l}\text { PIs able to bring researchers together across } \\
\text { disciplines and program-unifying themes }\end{array}$ \\
\hline Team members (PI et al) & $\begin{array}{l}\text { Possess complementary and intersecting skills } \\
\text { Able to develop common language } \\
\text { Positive open attitude } \\
\text { Appreciative of others' knowledge } \\
\text { Shared understanding of scientific problem } \\
\text { Mutual trust and respect } \\
\text { Open to mentoring others }\end{array}$ \\
\hline Training & $\begin{array}{l}\text { Complementary training } \\
\text { Mentored as grad students to participate in } \\
\text { transdisciplinary teams } \\
\text { SERCA grants for training in new field }\end{array}$ \\
\hline Institutions & $\begin{array}{l}\text { Support, promote, and fund centers, disciplines, } \\
\text { departments, and medical and social science } \\
\text { facilities }\end{array}$ \\
\hline Technology & $\begin{array}{l}\text { Facilitate communication even when on the same } \\
\text { campus teams and researchers are physically } \\
\text { dispersed }\end{array}$ \\
\hline Funding & $\begin{array}{l}\text { Foundations and government support } \\
\text { network/team approach (e.g. MacArthur, NIH) }\end{array}$ \\
\hline
\end{tabular}


Running Head: PI LEADERSHIP STYLE AND COLLABORATION

Table 3

Factors constraining transdisciplinary team science

\begin{tabular}{ll}
\hline Factor & Constraining \\
\hline Focus on major problems & Some areas seen as unrealistic \\
& Lack of integrative research framework \\
& Few "how to" models \\
\hline Team members (PI et al) & See skills as competitive \\
& Tension between solo and collaborative work \\
& Power-prestige differences social and medical sciences \\
& Worry about diffusion of focus and loss of identity \\
& Research seen as time-consuming/multiple projects \\
& Disincentive for practitioners \\
& Sharing credit affects promotion, tenure, publications, \\
& funding \\
\hline Training & Historical barriers across fields \\
& Location of departments \\
& Funding limited \\
\hline Institutions & Rigid university policies \\
& Centers lacking funds \\
\hline Funding & Grant applications more challenging, time-consuming \\
\hline Publication & Journals discourage multiple authors \\
& Peer review hard to judge \\
& Need to frame more narrowly \\
\hline
\end{tabular}

Note: Permission to use these tables was granted by Drs. Frank Kessel and Patricia Rosenfield (see Appedix A for email correspondence). PI, Principal Investigator

These factors refer to the array of institutional, team, and individual behaviors that enhance or hinder interdisciplinary research. This type of research has both high benefits and costs (Klein, 2010; Wuchty, Jones, \& Uzzi, 2007). Much of the early work in the science of team science centered on taxonomy, working to define and delineate the various definitions of interdisciplinary, cross-disciplinary, multi-disciplinary, and transdisciplinary research (Hall, Feng, Moser, Stokols, \& Taylor, 2008; Klein, 2010). As early as 1992 examples of crossdisciplinary health programs and the initial defining of terms "served as an entry point for much of the current discussion of health research across disciplinary boundaries" (Kessel \& 


\section{Running Head: PI LEADERSHIP STYLE AND COLLABORATION}

Rosenfield, 2008, p. S225). This discussion continues today, but given that the distinctions are small and there is considerable disagreement as to the nuances, many people use the terms interchangeably (Hall et al., 2008). Building on the taxonomy, much research is needed in the emerging field of team science.

Robert Croyle (2008), an official at the National Cancer Institute, advocates for further development of the science of team science. Integrated teams working on real world problems is becoming the standard and there is a clear need for a scientific approach to evaluation and impact studies related to the work of these teams. After reviewing the literature, Klein (2008) notes that there are seven areas in the science of team science where evaluation studies are needed: variability of goals; variability of criteria and indicators; leveraging of integration; interaction of social and cognitive factors in collaboration; management, leadership, and coaching; iteration in a comprehensive and transparent system; and, effectiveness and impact. Funders and leaders are calling for investigations that study how research teams interact, the significance of the interactions, and the outcomes of the partnerships. A group of like-minded researchers agree and in April 2010 held the first international science of team science conference in Chicago, IL with the goal of bringing together scientists from a variety of backgrounds to identify the key concepts related to this new field of study. Participants completed a concept mapping activity that categorized the following research directions for team science: definitions and models; disciplinary dynamics; structure and context for teams; institutional support and professional development; management and organization; and characteristics and dynamics of teams (FalkKrzesinski et al., 2010). This group continues its work today and recently held their fourth international conference (http://www.scienceofteamscience.org/). 


\section{Running Head: PI LEADERSHIP STYLE AND COLLABORATION}

Much of the most recent work in the science of team science focuses on measuring and documenting the productivity and impact of teams (Schnell, 2013; Wuchty, Jones, \& Uzzi, 2007), as well as creating a roadmap for the field (Falk-Krezenski et al., 2011; Hall, et al., 2012). In addition, the issue of tenure and promotion, discussed earlier in this chapter, persists as a constraining factor; if collaboration and team science is to move forward, academic institutions must continue to address the emphasis on individual assessment (Bunton \& Mallon, 2007; Klein, 2010; Petersen, Riccaboni, Stanley, \& Pammoli, 2012). Finally, with technology advancements and an ever changing funding climate, researchers are exploring the use of social media and the topic of sustainability (Leonardi, 2013; Pohl, 2013; Rosenfield, 2013). Figure 1 summarizes the changing research needs of the science of team science identified throughout the literature. The findings of this study on leadership and collaboration satisfaction contribute to the existing body of knowledge by addressing gaps related to structure and context, including leadership, relationships, personal/behavioral characteristics, and synergy. 
Running Head: PI LEADERSHIP STYLE AND COLLABORATION

Figure 1

Evolution of identified areas of research in the emerging field of the science of team science

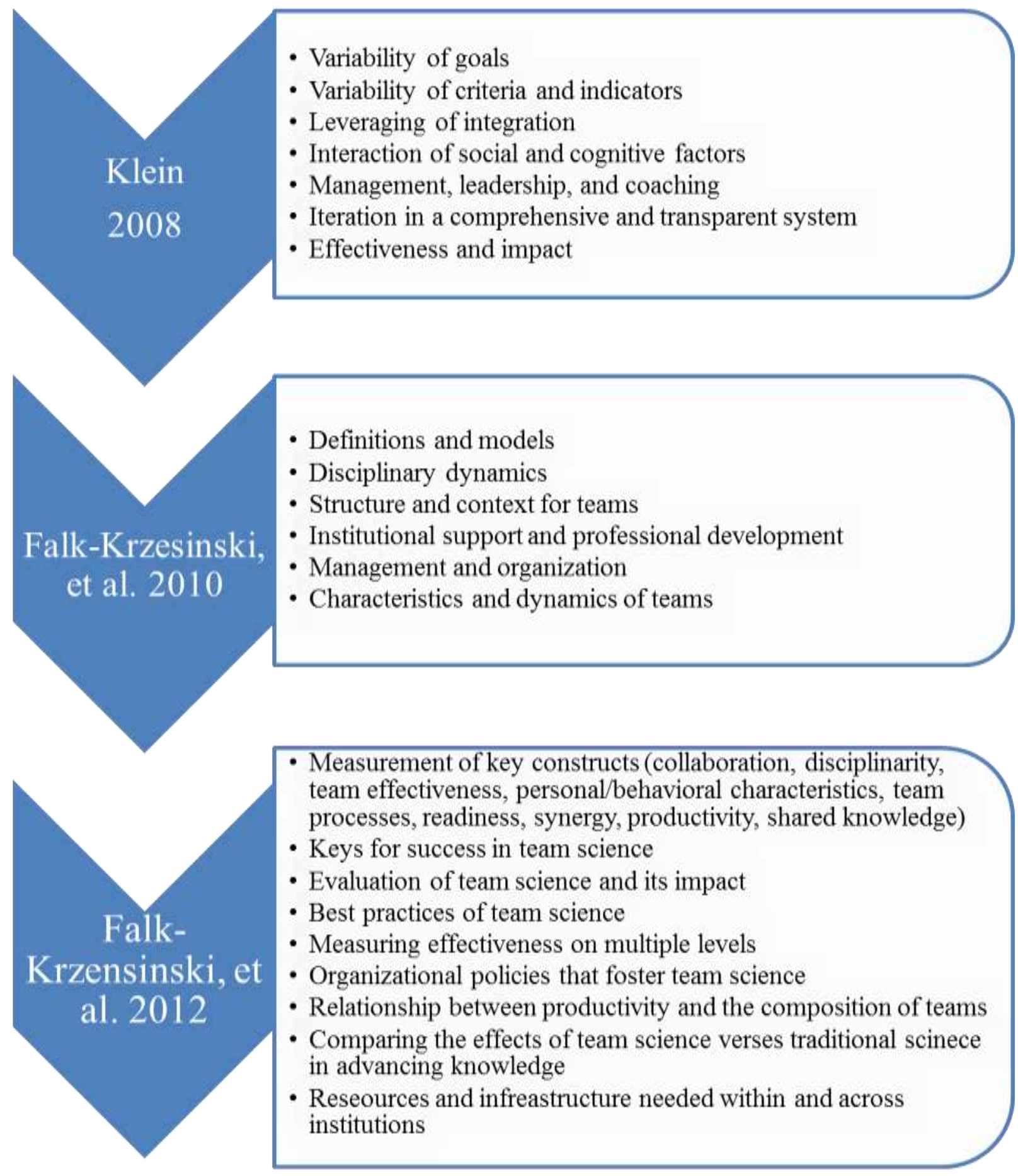




\section{Running Head: PI LEADERSHIP STYLE AND COLLABORATION}

\section{Leadership Theories}

Five main approaches or explanations of leadership styles have come to the forefront since the early 1900s (Hackman \& Johnson, 2004). These include the trait, behavioral, situational, functional, and transformational approaches. This section of the literature review highlights various theories related to these approaches and demonstrates how the theories build on one another.

The trait model, the first school of thought, held that "leaders possessed unique physical and psychological characteristics that predisposed them to positions of influence" (Hackman \& Johnson, 2004, p. 65). In 1948, Stogdill reviewed 124 studies that outlined traits related to leadership and documented many inconsistencies, but later research demonstrated that certain characteristics were associated with increased leader effectiveness. Bass (1981) built on Stodgill's work by analyzing an additional 200 studies, and summarized his work by stating:

The leader is characterized by a strong drive for responsibility and task completion, vigor and persistence in the pursuit of goals, venturesomeness and originality in problem solving, drive to exercise initiation in social situations, selfconfidence and sense of personal identity, willingness to accept consequences of decision and action, readiness to absorb personal stress, willingness to tolerate frustration and delay, ability to influence other persons' behavior, and capacity to structure social interaction systems to the purpose at hand. (p. 81)

This theory held that the more traits a leader possessed, the more effective his/her leadership abilities. Much of this research was based on observation rather than measurement and was therefore very subjective in nature (Bass, 1990; Yukl, 1998). Trait 


\section{Running Head: PI LEADERSHIP STYLE AND COLLABORATION}

theories fell out of favor in the 1950s and were replaced by a focus on behavior theories that aimed to measure the actions of leaders.

The Michigan and Ohio State Leadership Studies, both of which were completed shortly following World War II, set the stage for the development of the behavioral theories of leadership (Hackman \& Johnson, 2004). The Michigan Studies worked with teams of clerical and railroad workers and noted distinct leadership differences in those that were "employee-oriented" versus those that were "production-oriented." These researchers believed that leadership was one dimensional and a leader had to focus on either employees or production. On the other hand the Ohio State researchers, after administering and analyzing the Leader Behavior Description Questionnaire to groups of military personnel, determined that leadership was two dimensional with both an initiating structure and a consideration structure. Hoy and Miskel (2005) related initiating structure to the more bureaucratic functions of a leader including organizational hierarchy, communication channels, policies, and procedures, while coordinating structure refers to more collegial functions such as respect, trust, and warmth.

White and Lippett (1968) studied the communication behavior of leaders and their effects on the behavior of followers. Their three classic leadership styles are authoritarian, laissez-faire, and democratic. The authoritarian leader directs all aspects of a project one step at a time. These leaders maintain power and often remain aloof from the group. In direct contrast, laissez-faire leaders give followers complete freedom and only provide input when directly asked a question. Finally, the democratic leader includes followers in planning, implementation, and evaluation. This type of leader draws out group members and provides feedback while being actively 


\section{Running Head: PI LEADERSHIP STYLE AND COLLABORATION}

involved in the project. Groups led by democratic leaders tend to demonstrate higher productivity and satisfaction.

Finally, building on the work of these behavioral theorists, Blake and Mouton (1985) developed a managerial grid that consisted of five leadership styles built along two dimensions: task and relationship. The leadership styles associated with the grid included the authoritative manager (high task, low relationship), the impoverished manager (low task, low relationship), the middle of the road manager (adequate task and relationship), the country club manager (low task, high relationship), and the team manager (high task, high relationship). These researchers emphasized and clearly defined the two main component behaviors of leadership, but stopped short of identifying that managers and leaders could exhibit more than one style. There was clearly a situational aspect to Blake and Mouton's work that they never clearly delineated (Yukl, 2002).

The third school of leadership theories, situational leadership came to the forefront in the 1960s. These contingency-focused researchers built upon the earlier work of the behavioral theorists, but demonstrated that there were social determinants associated with the style of leadership. These determinants included organizational structure, role characteristics, follower traits, and internal and external influences (Hoy \& Miskel, 2005). This body of theories was based on the premise that differing situations call for changes in leadership style and that leaders must be able to correctly diagnose the situation and act accordingly.

Hersey and Blanchard (1996) developed their theory of situational leadership in the 1960s on the premise that the maturity of the follower influenced the style of leadership required. Figure 2 illustrates the four quadrants in this model and their corresponding leadership style. 
Running Head: PI LEADERSHIP STYLE AND COLLABORATION

Permission to use this figure was granted by the Center for Leadership Studies (see Appendix B for email correspondence). In quadrant one, the follower commitment and maturity are both low, calling for a highly directive management style with low relationship behavior. Quadrants two and three demonstrate a higher level of maturity with varying commitment, thus calling for a leader who supports both types of followers, but in quadrant two, the leader provides more direction. Finally, Quadrant four depicts a mature follower who requires little direction and/or support; this leader must adapt to a follower's independence and need for increased responsibility (Hackman \& Johnson, 2004).

Figure 2

Hersey and Blanchard's Situational Leadership Theory

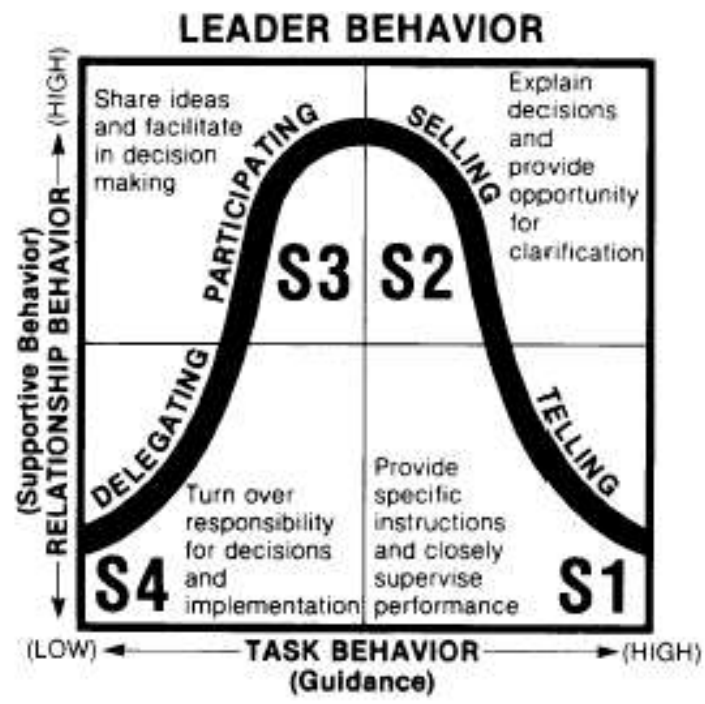

Note. (C) Copyright 2006 reprinted with permission of the Center for Leadership Studies, Escondido, Ca.

Finally, the Path-Goal Theory was tied to the expectations of followers; the researchers found that a follower is more likely to produce if they see task completion as part of a bigger goal. This required that a leader clearly communicate the goals and mission of the organization, as well as identify expectations and recognize achievement. 


\section{Running Head: PI LEADERSHIP STYLE AND COLLABORATION}

Situational leadership was replaced by a functional approach that found its roots in the earlier work of Chester Barnard who identified communication as the cornerstone of functional leadership theory (Hackman \& Johnson, 2004). In this model communicating the vision, mission, goals, and expectations of the organization rested with the leader and required some understanding of group dynamics and the various roles members assume. Group members displayed roles that are task-related, group building, and individually oriented (Benne \& Sheats, 1948). By analyzing the actions of followers, leaders could more clearly communicate their message which in turn increased their ability to successfully lead.

These varying leadership theories build on one another, indicating that certain traits, behaviors, situations, and communication styles are important, but none fully explain the key to successful leadership. The concept of transformational leadership adds to these earlier studies and provides a more comprehensive view of the characteristics and behaviors demonstrated by successful leaders (Bennis \& Nanus, 1997; Kouzes and Posner, 1995; Neff \& Citrin, 1999; Peters \& Austin, 1985; Peters \& Waterman, 1982). Transformational leaders are creative, visionary, empowering, passionate, and highly interactive with their followers. These leaders raise the level of performance and commitment of their followers. Success rests on the leader who communicates and acts on these convictions in varying situations.

This section of the literature review highlights leadership theories from the varying schools of thought: trait, behavioral, situational, functional, and transformational. The definitions, premises, and related research are helpful in understanding the history of leadership, as well as the conditions needed for success. The theories build on one another and are not exclusive. Often times multiple approaches to a situation assist a 
Running Head: PI LEADERSHIP STYLE AND COLLABORATION

leader in meeting goals. One such theory, the four frame approach, is a comprehensive paradigm that increases a leader's ability to view a situation through different lenses

(Bolman \& Deal, 1991).

\section{Leadership Frames and Styles}

In Reframing Organizations, Artistry, Choice and Leadership, Bolman and Deal (2003)

identified how maintenance of core beliefs and use of a multi-frame approach improves

leadership and leads to organizational efficiency. They explored the structural, human resource, political, and symbolic frames and demonstrated how the use of multiple frames serves as "maps that aid navigation, and tools for solving problems and getting things done" (Bolman \& Deal, p.18). Looking at managerial issues from differing views enhances leadership and leads to greater creativity in problem solving.

The structural frame relates to strategic planning, goal setting, policy making, and fact finding in an organization. There is an emphasis on resource management, policy and procedures, and roles and responsibilities. Utilitarian team functions, especially providing information, coordinating, planning, and making decisions, are central to the structural frame. Managers utilize data, the organizational chart, and the financial statement as management tools. Use of management theory and best practices guides managers utilizing the structural frame. They tend to respond to external pressures through a subsequent change in management techniques, realignment of roles, review of the structure of the organization, and identification of strengths and weaknesses. Organizational effectiveness and efficiency are hallmarks of the structural frame.

In comparison, the human resource frame focuses on human needs and how the organization addresses and meets those needs. Managers are called to take care of staff and pull 


\section{Running Head: PI LEADERSHIP STYLE AND COLLABORATION}

people together. Shared decision making, open communication, and an emphasis on mutual responsibility are central when viewing an organization through this frame. The human resource frame values input from the group and recognizes the achievements of others. Administrators utilize strong communications skills and maintain an open process. They keep people involved and align the organization to meet human needs. By involving faculty and staff, leaders increase institutional commitment and create faculty and staff buy-in. Leaders who use this lens pull in their opposition, spend time building internal relationships, and facilitate open communication.

The political frame, on the other hand, centers on power, conflict, and bargaining. Leaders must build bridges and manage differing agendas and conflicts within and outside the organization. Competing for scarce resources and brokering deals are key components of this frame. Status is important for political leaders and decision making allows them the opportunity to exercise their power. Building coalitions and balancing power are important skills for these leaders. They tend to have a strong power base and know when to pursue certain agendas and call in favors.

Finally, the symbolic frame emphasizes the maintenance of institutional culture, tradition, and values. Culture overcomes uncertainty; provides motivation; improves collaboration; fosters successful change; builds commitment and identification; and amplifies vitality. Administrators utilizing this frame are likely to build a collegial and collaborative atmosphere by adhering to institutional values, emphasizing history, and using symbols intentionally. These leaders use symbols to express their goals, build morale, discuss vision, and convey a myriad of ideas and beliefs. They engage in a "management of meaning" where core values give rise to a shared sense of mission and identity. The symbolic frame references the "heart and soul" of an institution. 


\section{Running Head: PI LEADERSHIP STYLE AND COLLABORATION}

Through a series of on-site interviews, Bensimon (1989) characterized the leadership styles of university administrators as single, paired, or multi-framed. She stated that:

a frame represents a distinctive cognitive lens that helps the manager of an organization or the president of a college determine what is important and what can safely be ignored. Cognitive frames determine what questions might get asked, what information is collected, how problems are defined, and what courses of action should be taken. (Bensimon, p. 421)

A leader who uses only one frame is said to be single frame, a leader using two frames is considered paired frame, and a leader utilizing more than two frames is multi-frame. A leader who utilizes more than one frame is likely to be more effective and efficient than one employing a single frame (Bensimon, 1989; Bolman \& Deal, 1984, 1991, 1992).

Gray (2008), a contributing author to the American Journal of Preventive Medicine's special edition dedicated to the emerging field of team science, completed a review of leadership literature and determined that interdisciplinary research teams are best lead by those able to engage in cognitive, structural, and processual tasks. These tasks mirror the model set forth by Bolman and Deal as illustrated in Figure 3. Gray's cognitive tasks cover both the symbolic and political domains. The structural task and frame are identical in purpose while the processual tasks represent the human resource frame. These models are so similar that measurement of leadership in interdisciplinary research teams, called for by Klein (2008), can be achieved using the Bolman and Deal Leadership Orientations (Others) instrument. 
Figure 3

Relationship of Gray's Tasks to Bolman and Deal's Frames

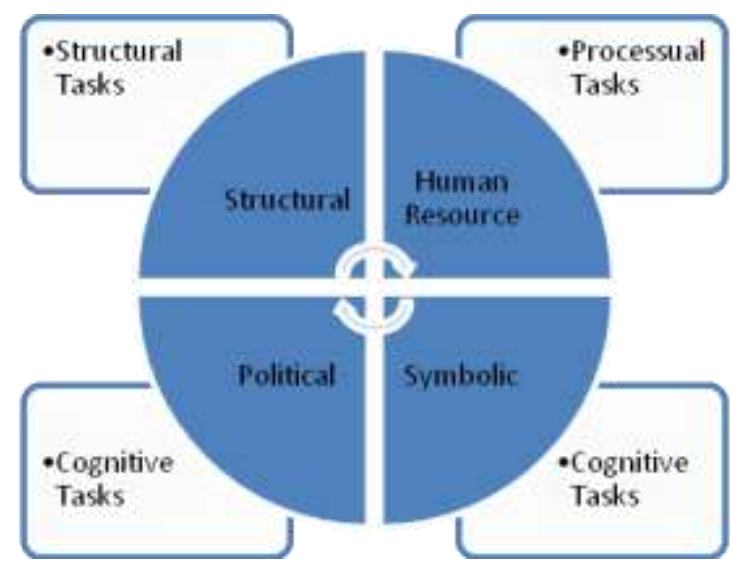

\section{Measurement of leadership and collaboration satisfaction}

The Leadership Orientations (Others), developed by Bolman and Deal and copyrighted in 1990, is a survey instrument using their four-frame theory that measures individuals' orientations toward leading. The "others version" means that the principal investigators are rated by their team members and does not take into account self-report of leadership orientation. Numerous studies have been completed using this instrument. In addition to those already discussed in the literature review completed by Bensimon and Bolman and Deal, additional studies in higher education utilize the Leadership Orientations instruments (Borden, 2000; Cantu, 1997; Mathis, 1999; Mosser, 2000; Small 2002; Chang, 2004).

In terms of frame utilization, these researchers found that the human resource frame was used most by chairs, area campus administrators, and deans (Borden, 2000; Cantu, 1997; Mathis, 1999; Mosser, 2000; Small 2002; Chang, 2004). In most studies this was followed by the structural frame, but Mathis (1999) and Borden (2000) both found that the symbolic frame ranked second in use by chairs and area campus administrators. In addition, Mathis concluded 


\section{Running Head: PI LEADERSHIP STYLE AND COLLABORATION}

that leaders who demonstrated a predominant symbolic frame had faculty members with higher intrinsic and overall job satisfaction ratings. Finally, Cantu (1997) compared randomly selected deans with deans identified as exceptionally effective by institutional leaders and concluded that although deans had a preference for the human resource frame, those rated as exceptional tended to utilize the political frame more than the randomly selected deans.

These studies identified that leaders in higher education represented the spectrum in terms of leadership style. Borden (2000) and Turley (2002) had samples where nearly half of the leaders were multi-frame while Chang (2004) only identified $15 \%$ of chairs in departments of education as multi-frame. On the other end of the continuum, Chang (2004) had slightly more than $56 \%$ of chairs with a no frame style along with Small (2002) who found in her study with chairs of nursing that the no frame style was most cited by followers. The range for single frame leaders was from 15\% (Chang, 2004) to nearly 41\% (Bensimon, 1989); across these studies this result was similar for the paired frame.

In summary, these researchers identified that the human resource frame is utilized the most regardless of academic position (dean, area administrator, or chairs). They also found that frame usage is influenced by a variety of factors including years of experience, gender, department size, department type (discipline), and highest degree attained.

In addition to the Bolman and Deal instrument, this study used the Collaboration and Transdisciplinary Integration Survey. This instrument was developed by Masse, Moser, Stokols, Taylor, Marcus, Morgan, Hall, Croyle, and Trochim (2008) to measure satisfaction with collaboration, impact of collaboration, trust and respect, and transdisciplinary integration. Researchers $(\mathrm{N}=216)$ participating in the Transdisciplinary Tobacco Use Research Centers completed this survey in order to test the instruments reliability and validity; this was the only 


\section{Running Head: PI LEADERSHIP STYLE AND COLLABORATION}

published study to date utilizing this instrument. The psychometric properties of both of these instruments are described in greater detail in Chapter 3.

\section{Summary}

This literature review includes information on academic health science centers, collaboration, interdisciplinary research teams, leadership, Bolman and Deal's leadership frames, and instrumentation. The results of a number of studies using the two instruments are highlighted. The literature review provides the foundation for the methodology section detailed in Chapter 3. 
Running Head: PI LEADERSHIP STYLE AND COLLABORATION

\section{Chapter 3}

\section{Methods}

This study aims to measure the satisfaction levels of members of collaborative research teams, and to discern if there is a difference in satisfaction related to effects of PI leadership style in interdisciplinary research teams in academic health science centers. This chapter discusses the methods utilized in the study and is organized into the following sections: participants, instrumentation, research design, procedures, data analysis, approach to missing values, confidentiality, and summary.

\section{Participants}

The population for this study included interdisciplinary research teams from Academic Health Science Centers in the United States. The population surveyed consisted of research team members (co-investigators, professional staff, laboratory staff, students, and other) identified as having National Institutes of Health (NIH) funded interdisciplinary research. The sample of institutions included Academic Health Science Centers in the United States that were members of the Association of Academic Health Centers with a Carnegie Classification of Research University (very high research activity) (see Appendix C for a list of these institutions). This study was regional so each of the institutions surveyed was within a 350 mile radius of Morgantown, West Virginia. The funded Principal Investigators (PIs) at each of these centers were asked to complete a Team Identification Form. Interdisciplinary teams were identified by the PIs and then surveyed using an online instrument that included the assessment questions from the Demographic Questionnaire, Bolman and Deal Leadership Orientations (Others), and Collaboration and Transdisciplinary Integration Survey. Only teams with three or more members responding to this survey instrument were used in the data analysis. 
Running Head: PI LEADERSHIP STYLE AND COLLABORATION

To determine an adequate sample size, an online calculator was used

(http://www.euclid.psych.yorku.ca/cgi/power.pl). To calculate sample size for a one-way ANOVA model with four levels of the independent variable, the significance level was set at 0.05. In order to achieve a minimal acceptable power of 0.80 , a sample of at least 160 (40 individuals per level x 4 levels) participants was required for this study.

\section{Team identification}

Regional PIs with funded projects from the National Institutes of Health whose institutions were members of the Association of Academic Health Centers with a Carnegie Classification of Research University (very high research activity) were contacted and asked to complete a Team Identification Form online. E-mails were sent to 3,043 funded PIs from eight Academic Health Science Centers (see Appendix D for the initial institutional scripts). More than 600 PIs opened the online survey, while 203 completed the form. Of the completed surveys, 72 identified that they were not conducting interdisciplinary team research and 31 were not willing to identify the names of their team members. A total of 100 PIs completed the Team Identification Form confirming that their research was being conducted by an interdisciplinary team and identifying those team members; this group of respondents represented the accessible population.

\section{Survey responses}

The accessible population of this study encompassed 100 interdisciplinary research teams made up of 631 individuals. The sample included all members of the accessible population. After an initial mailing explained the study and provided instructions for online completion of the instrument, two reminder e-mails were sent at two week intervals (see Appendix E for introductory e-mail). A total of 236 individuals, representing 81 teams completed the survey. 
Running Head: PI LEADERSHIP STYLE AND COLLABORATION

Only teams with three or more members responding to the survey were used for data analysis; surveys that only included responses to the demographic questions were not included in the final sample. The sample used for analysis included 170 individuals from 38 teams at 7 institutions. The individual response rate was $37.4 \%$ representing $81.0 \%$ of the teams asked to participate. Of those, $72.0 \%$ of the individuals and $46.9 \%$ of the teams were included in the analyzed data set. Figure 4 summarizes the sampling process.

Figure 4

Sample Process Summary

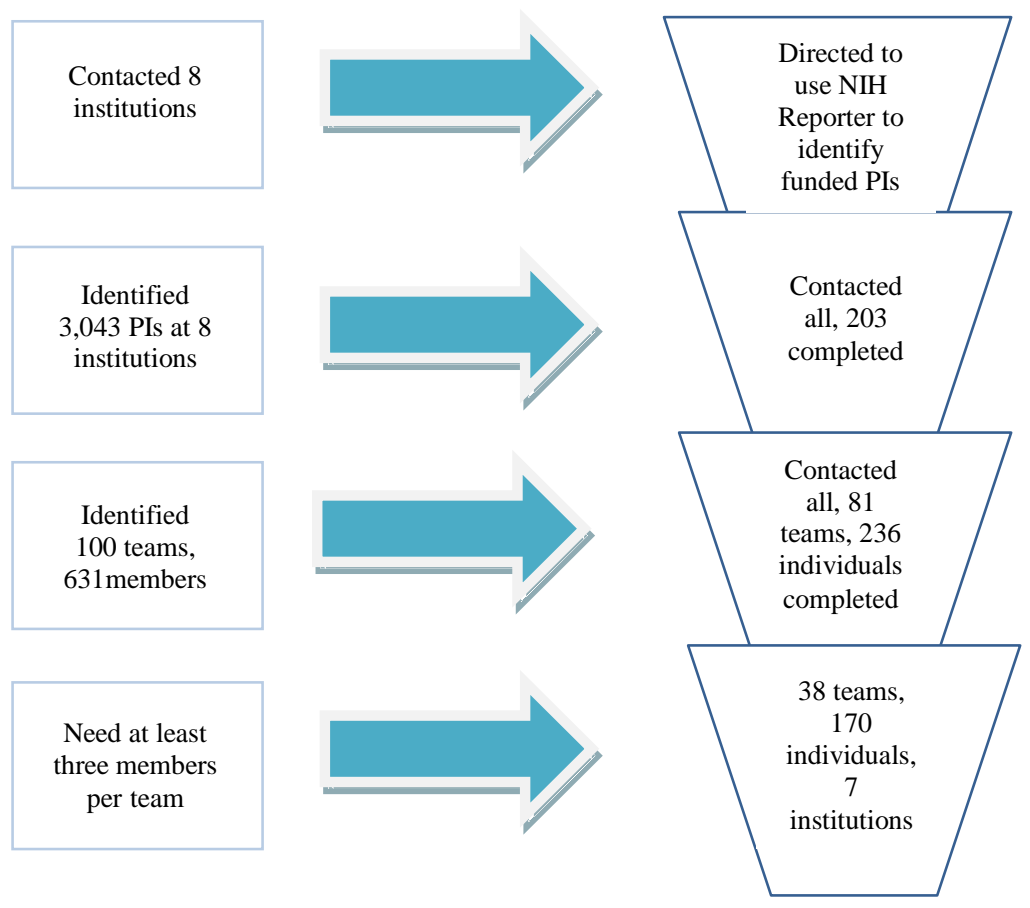

Respondent data. Table 4 reports the demographic data for team members. The respondents included individuals from Schools of Medicine (68.8\%), Schools of Nursing (3.5\%), Schools of Dentistry (1.2\%), a School of Pharmacy (0.6\%), and other schools, colleges, and departments within the institution (24.1\%), including Public Health, Engineering, Veterinary 
Running Head: PI LEADERSHIP STYLE AND COLLABORATION

Medicine, Health Education, Social Work and others; $1.8 \%$ of respondents did not specify their primary academic appointment. There were 76 males (44.7\%) and 94 females $(55.3 \%)$ who completed surveys and nearly $75 \%$ reported that their institutional positions were supported from multiple sources. Nearly half of the respondents reported that they served as coinvestigators (48.8\%) and an additional 19\% responded that they held professional staff positions on the research team; $16.5 \%$ identified that they fell into the other category which included post-doctoral fellows, post-doctoral research associates, and research support staff. Table 4

Demographic Variables of Respondents

$\mathrm{N}$

Primary academic appointment of respondent

School of medicine

School of nursing

School of dentistry

School of pharmacy

Other

Did not specify

$\begin{array}{rr}117 & 68.8 \% \\ 6 & 3.5 \% \\ 2 & 1.2 \% \\ 1 & 0.6 \% \\ 41 & 24.1 \% \\ 3 & 1.8 \%\end{array}$

Percent

Gender of respondent

Male

76

$44.7 \%$

Female

94

$55.3 \%$

$100 \%$ support on one grant

Yes

42

No

126

Did not respond

Respondent role on research team

Co-investigator

Professional staff

Laboratory staff

Student

12

Other

28

Did not specify

$18.8 \%$

$7.6 \%$

$7.1 \%$

$16.5 \%$

$1.2 \%$ 
Running Head: PI LEADERSHIP STYLE AND COLLABORATION

Principal investigator data. Principal investigator (PI) demographics are featured in

Table 5. The team members identified that 22 PIs (57.9\%) were male and $16(42.1 \%)$ were female and more than half (52.6\%) led teams comprised of six to ten members. The teams also reported that this group of research leaders were experienced as nearly $75 \%$ had served as a PI for more than six years.

Table 5

Demographic Variables of Principal Investigators

N Percent

Gender of PI

Male

Female

$22 \quad 57.9 \%$

$16 \quad 42.1 \%$

Size of research team

5 members or less

$6 \quad 15.8 \%$

Between 6 and 10 members $\quad 20 \quad 52.6 \%$

11 members or greater $\quad 12 \quad 31.6 \%$

Number of years PI served as a PI

Less than 3 years

4 or 5 years

$6 \quad 15.8 \%$

Longer than 6 years

$4 \quad 10.5 \%$

$28 \quad 73.7 \%$

\section{Instrumentation}

This research utilized four instruments: a Team Identification Form (see Appendix F), a Demographic Questionnaire (see Appendix G), the Bolman and Deal's Leadership Orientations (Others) (see Appendix H), and the Collaboration and Transdisciplinary Integration Survey (see Appendix I ). The Team Identification Form was completed by PIs and was used to identify if a research team was defined as interdisciplinary, and if so, to then identify the names and e-mail addresses of team members. The Demographic Questionnaire was completed by team members 
Running Head: PI LEADERSHIP STYLE AND COLLABORATION

and identified basic information about the member, team, and PI. The Leadership Orientations instrument was completed by team members identified as being part of an interdisciplinary research team to collect data to identify the PIs' leadership styles, while the survey of Collaboration and Transdisciplinary Integration was used to measure satisfaction with collaboration, impact of collaboration, trust and respect, and transdisciplinary integration. For the completion of this study, online versions of the surveys were developed using the Zoomerang Online Survey Software.

Team identification form. The Team Identification Form, developed by the researcher, determined eligibility for the team's potential participation in the study. Funded PIs were contacted via e-mail and asked to complete this form. It consisted of six items: the institution, project name, PI name, interdisciplinary team status, team members' names, team members' email addresses, and an open-ended item inviting the researcher to share any other information s/he deemed necessary.

Demographic questionnaire. The Demographic Questionnaire, developed by the researcher, gathered basic information regarding the participant's gender, role on the research team, most advanced degree, and primary departmental affiliation. In addition the participant's identified the gender of the PI, the size of the research team, and the number of years the Principal Investigator served as a PI; previous studies using the Bolman and Deal (others) instrument identified that frame usage is influenced by these factors (Borden, 2000; Chang, 2004) .

Leadership orientations (others). The Leadership Orientations (Others), developed by Bolman and Deal and copyrighted in 1990, is a survey instrument using their four-frame theory that measures individuals" orientations toward leading. The "others version" means that the 
Running Head: PI LEADERSHIP STYLE AND COLLABORATION

principal investigators are rated by their team members and does not take into account self-report of leadership orientation. This instrument consists of four rating scales with items used to determine the frame(s) that the principal investigator demonstrates. Permission to use the instrument was granted by Dr. Lee Bolman (see Appendix J for email correspondence).

Each of the four frames of leadership was represented by eight items in this 32 item instrument. The items were in a consistent frame sequence: structural (items 1, 5, 9, 13, 17, 21, 25, 29), human resource (items 2, 6, 10, 14, 18, 22, 26, 30), political (items 3, 7, 11, 15, 19, 23, 27, 31) and symbolic (items 4, 8, 12, 16, 20, 24, 28, 32). Respondents used a five-point Likert scale to rate the degree to which their principal investigator exhibits each leader behavior $(1=$ Never, 2 = Occasionally, $3=$ Sometimes, $4=$ Often, and $5=$ Always $)$. A principal investigator with a mean score on the questions of a section equal to or above 4.0 was classified as using that leadership frame.

The reliability data for the Leadership Orientations instrument was determined on the basis of 1309 colleague ratings for a multi-sector sample of managers in business and education reported on the Web page titled as Potential Users of Leadership Orientations Instruments (www.leebolman.com/orientations). The split half correlation for four frames ranged between 0.837 to 0.882 , the Spearman-Brown coefficient ranges between 0.911 to 0.937 and Guttman (Rulon) coefficient exceeds 0.900. Additionally, Cronbach's alpha for the frames ranged from 0.910 to 0.930 (Bolman \& Deal, 1991b). To date, no studies reported any validity data for this instrument. The Leadership Orientations (Others) survey instrument was used in numerous studies to determine the leadership styles of those working in higher education (Bensimon, 1989; Bethel, 1998; Bolman \& Deal, 1991; Borden, 2000; Cantu, 1997; Mathis, 1999; Mosser, 2000; Small, 2002; Turley, 2002). 
Running Head: PI LEADERSHIP STYLE AND COLLABORATION

Collaboration and transdisciplinary integration survey. This instrument was developed by Masse et al. (2008) to measure satisfaction with collaboration, impact of collaboration, trust and respect, and transdisciplinary integration. The instrument is divided into two sections measuring the identified four subscales. The first section of the instrument, consisting of 18 items measures satisfaction, impact, and trust and respect. Items 1 - 11 measure the satisfaction and some aspects of the impact of collaboration; respondents will be asked to rate these items using a five-point Likert scale $(1=$ inadequate, $2=$ poor, $3=$ satisfactory, $4=$ good, 5 = excellent). Items 12 - 18 measure the remaining aspects of impact, as well as trust and respect; participants will rate these items on the following Likert scale: $1=$ strongly disagree, $2=$ somewhat disagree, $3=$ not sure, $4=$ somewhat agree, $5=$ strongly agree. The second section of the instrument measures transdisciplinary integration and respondents will rate their attitudes about transdisciplinary research $(1=$ strongly disagree, $2=$ somewhat disagree, $3=$ not sure, $4=$ somewhat agree, $5=$ strongly agree). For the purposes of this research, only items $1-8$ of section one will be used as they are the items identified as measuring collaboration satisfaction.

Permission to use the instrument was granted by Dr. Louise Masse (see Appendix I for email correspondence).

The instrument was tested with 216 researchers and interdisciplinary team members participating in the Transdisciplinary Tobacco Use Research Centers, located in universities around the country (Masse, 2008). Internal consistency was calculated using SPSS to compute Cronbach's alpha. For items $1-8$, Cronbach's alpha $=0.91$, for items $1-14,0.87$, and for items $15-18,0.75$. Factorial validity was completed for each of the subscales and the instrument was correlated with the intermediate markers in a logic model designed to evaluate large research initiatives; the hypothesized factor structures were validated. 
Running Head: PI LEADERSHIP STYLE AND COLLABORATION

\section{Research design}

To determine if there was a statistically significant difference in the collaboration satisfaction of research team members who have PIs with different leadership styles, the leadership styles were determined as a first step. Then that leader's style was compared to the scores on the first subscale of the Collaboration and Transdisciplinary Integration Survey.

In this study, the two variables were the leadership style of the principal investigator and the satisfaction of interdisciplinary team members. The independent variable (leadership) was categorical while the dependent variable (collaboration satisfaction) was quantitative. In addition, the study measured the impact of the potential confounding variable of PI gender, PI experience (less than three years, four to five years, and longer than six years), and research team size (less than five members, six to ten members, and greater than ten members). This study utilized the causal-comparative research design because the goal was to determine if there was an effect of leadership style on satisfaction. Research questions 3 and 4 explored potential reasons (dominant frame and style) for a difference in the collaboration satisfaction of interdisciplinary research teams. The limitations of causal-comparative research include "lack of randomization, manipulation, and control" (Gay, Mills, \& Airasian, 2006, p. 221). In addition, research questions 1, 2, and 5 utilized a descriptive research design in order to identify the frames and styles of leaders, collaboration satisfaction of team members, gender and experience level of principal investigators, and size of the research teams. Descriptive studies are limited by their reliance on self-report and the potential lack of response (Gay, Mills, \& Airasian, 2006).

\section{Procedures}

The research protocol was first submitted to the West Virginia University Institutional Review Board for the Protection of Human Subjects for approval. Following the approval and 
Running Head: PI LEADERSHIP STYLE AND COLLABORATION

subsequent identification of the potential participating institutions an invitation to the research office was extended via the telephone and e-mail. A brief screening of these facilities was conducted to ascertain their willingness to participate and to identify that they have at least one team of interdisciplinary researchers engaged in a funded project. Once confirmation of this information was completed, the directors referred the researcher to the NIH Research Portfolio Online Reporting Tools (http://projectreporter.nih.gov/reporter.cfm) for a list of PIs funded at their institutions.

Each research team was assigned a unique identifier to ensure tracking of team member responses. All of the team members received an introductory e-mail with an electronic link to the surveys. Reminder e-mails were sent every two weeks in a six week period to encourage completion of the survey. An incentive was used in this study. At the end of the electronic survey respondents who were interested in entering a drawing for a pre-paid \$100 Visa gift card were asked to click on an additional link that took them to a secure site where they could enter their contact information. Each respondent was linked to a number between one and 101 and a number was chosen at random. The corresponding participant was awarded the gift card via the United States Postal Service. The incentives and the follow-up efforts were utilized in an effort to increase the return rate.

\section{Data analysis}

The data for this study were generated from the Demographic Questionnaire, Bolman and Deal's Leadership Orientations (Others), and the Collaboration and Transdisciplinary Integration Survey. The Statistical Package for the Social Sciences, SPSS 20, was utilized for statistical computation. An alpha level of .05 was the level of significance for this study. The statistical methods used to analyze the data are listed beneath each of the research questions. 
Running Head: PI LEADERSHIP STYLE AND COLLABORATION

Research question 1. What are the leadership styles (as measured by the frames) of the principal investigators of interdisciplinary research teams?

The Bolman and Deal Leadership Orientations (Others) was utilized to answer this question. The overall mean and standard deviation of each frame were computed. Then the mean for each frame for each PI was computed. A PI whose scores reported by his/her team as a 4.0 or higher were identified as espousing that frame. The frequency of respondents espousing each frame was quantified. Frequencies and percentages of the principal investigators who utilized different patterns of no, single, paired, and multi-frame were also identified and presented.

Research question 2. What is the collaboration satisfaction of interdisciplinary research teams?

The Collaboration and Transdiciplinary Integration Survey was utilized to answer this question. The overall mean and standard deviation across all teams was computed. Then the mean for each multidisciplinary team was computed so that the range in variability in satisfaction across teams could be assessed. Frequencies and percentages for each Likert scale response were calculated.

Research question 3. Is there a statistically significant difference in the collaboration satisfaction scores of research team members who have principal investigators with different dominant leadership frames (structural, human resource, political, and symbolic)?

The data used to answer this research question were generated from the Collaboration and Transdisciplinary Integration Survey and the Leadership Orientations (Others) Survey. A one-way ANOVA with post hoc analysis was used to determine if there was a statistically significant difference in collaboration satisfaction in teams led by PIs with different dominant frames (structural, human resource, political, or symbolic). 
Running Head: PI LEADERSHIP STYLE AND COLLABORATION

Research question 4. Is there a statistically significant difference in the collaboration satisfaction of research team members who have principal investigators with different leadership styles (no, single, paired, or multi-framed)?

The data used to answer this research question were generated from the Collaboration and Transdisciplinary Integration Survey and the Leadership Orientations (Others) Survey. A one-way ANOVA with post hoc analysis was used to determine if there was a statistically significant difference in collaboration satisfaction in teams led by PIs with different leadership styles. There was only one leader with a single frame style and only three members on the team so this team's data was excluded from the analysis.

Research question 5. How does the leadership style of principal investigators vary by demographic variables of gender, length of time as principal investigator (less than 3 years, 4 to 5 years, and longer than 6 years), and the size of research team (the number of team members is less than 5, between 6 and 10, and greater than 11)?

An analysis using the chi-square test for goodness of fit was planned to test if there was a statistically significant difference in these variables, but based on the responses to the Leadership Orientations (Others) Survey and the demographic questions, a majority of team members identified their leaders as experienced and multi-frame. This resulted in an insufficient sample size for chi-square analysis so the question could only be answered descriptively.

\section{Approach to dealing with missing values}

Item non-response for this study was minimal. There were five cases where respondents only answered the demographic questions. In these cases the data for those individuals were removed from the final data set. When respondents failed to complete individual items on the measurement scales, each subscale mean was computed by using the scores of other items 


\section{Running Head: PI LEADERSHIP STYLE AND COLLABORATION}

answered by that respondent and their team members. For the Leadership Orientation, Others instrument there were a potential of 5440 responses and for the data set 22 were left blank, representing $0.40 \%$ as missing. The collaboration satisfaction subscale from the Collaboration and Transdisciplinary Integration Survey included a potential 1360 responses and 25 were left blank, representing $1.84 \%$ as missing.

\section{Confidentiality}

The completion of this study depends on responses from human subjects and requires their voluntary participation, their confidentiality was protected consistent with IRB standards and policies. The cover letter informed the subjects: (1) of the purpose of the research, (2) that their participation is voluntary, (3) they have the right not to respond to every item, (4) confidentiality will be maintained, and (5) all information associated with the results of this study will be reported as de-identified information. Subjects' names were not requested on either instrument; only institutional coordinators knew the names of the participants, the researcher was blind to this level of information. The method used to classify the participants by institution was a code that was placed on each survey before it is distributed. Only the researcher understood the meaning of the code. The code was stored in a locked cabinet and destroyed upon completion of the study or until no longer needed.

\section{Summary}

In this chapter the basic methods and procedures of this study were discussed. The causal-comparative research design was identified as the appropriate design to determine if there is an effect of leadership style on satisfaction. The research questions were tied to the appropriate statistical analysis, which serve as the basis for the results section in Chapter 4. 
Running Head: PI LEADERSHIP STYLE AND COLLABORATION

Chapter 4

\section{Results}

This chapter presents the results of survey responses related to leadership styles of principal investigators (PIs) in academic health science centers and the collaboration satisfaction of team members serving on interdisciplinary research teams. The chapter includes an analysis of the data within the framework of the five research questions and ends with a summary of the major findings.

\section{Major findings}

This section presents major findings of the data analysis as it pertains to the research questions in this study. The .05 level was used for all statistical tests to establish statistical significance.

Research question 1. What are the leadership styles (as measured by the frames) of the principal investigators of interdisciplinary research teams?

Table 6 presents the means and standard deviations of teams' perceptions $(n=38)$ of leadership style (as measured by the four frames) for PIs on interdisciplinary research teams. The human resource frame had the highest mean $(\mathrm{M}=4.25, \mathrm{SD}=0.46)$, followed by the structural frame $(M=4.17, S D=0.46)$ and the symbolic frame $(M=4.14, S D=0.40)$. The political frame had the lowest mean $(\mathrm{M}=4.12, \mathrm{SD}=0.42)$. 
Running Head: PI LEADERSHIP STYLE AND COLLABORATION

Table 6

Means and Standard Deviations of PI Leadership Frames Rated by Teams

\begin{tabular}{lll} 
Frame & Mean & Standard Deviation \\
\hline Structural & 4.17 & 0.46 \\
Human Resource & 4.25 & 0.46 \\
Political & 4.13 & 0.42 \\
Symbolic & 4.14 & 0.40 \\
\hline
\end{tabular}

A mean score of 4.0 or higher for the leadership frame represents usage of that frame. Based on the mean score for each frame, the PIs of interdisciplinary teams used all of the frames, but were more likely to use the human resource and structural frames.

Table 7 identifies the frequency distribution of frame use by principal investigators (PIs) as perceived by their research teams. According to the teams, only one leader each occasionally used the structural and political frames. Approximately one quarter of PIs were perceived to sometimes use the structural and political frames while $18 \%$ sometimes used the human resource frame and just over 30\% sometimes used the symbolic frame. Team ratings identified that $71.1 \%$ of PIs $(n=27)$ often used the structural frame; $81.6 \%(n=31)$ often used the human resource frame; $73.7 \%(n=28)$ often used the political frame; and $68.4 \%(n=26)$ often used the symbolic frame. 
Running Head: PI LEADERSHIP STYLE AND COLLABORATION

Table 7

Frequency Distribution for Frame Use by Principal Investigators $(n=38)$

\begin{tabular}{lccc}
\hline Frame & Mean Score Range & Frequency & Percent \\
\hline Structural & $1-1.9$ & & $0.0 \%$ \\
& $2-2.9$ & 0 & $2.6 \%$ \\
& $3-3.9$ & 1 & $26.3 \%$ \\
& $4-5$ & 10 & $71.1 \%$ \\
Human Resource & $1-1.9$ & 27 & $0.0 \%$ \\
& $2-2.9$ & 0 & $0.0 \%$ \\
& $3-3.9$ & 0 & $18.4 \%$ \\
Political & $4-5$ & 7 & $81.6 \%$ \\
& $1-1.9$ & 31 & $0.0 \%$ \\
& $2-2.9$ & & $2.6 \%$ \\
& $3-3.9$ & 1 & $23.7 \%$ \\
Symbolic & $4-5$ & 9 & $73.7 \%$ \\
& $1-1.9$ & 28 & $0.0 \%$ \\
& $2-2.9$ & & $0.0 \%$ \\
& $3-3.9$ & 0 & $31.6 \%$ \\
& $4-5$ & 12 & $68.4 \%$
\end{tabular}

Note. The response scale for leadership frame: $1=$ never, $2=$ occasionally, $3=$ sometimes, $4=$ often, and $5=$ always.

The interplay of the frame data allowed the investigator to determine the leadership style of PIs of interdisciplinary research teams. The team members' ratings of the PIs were analyzed according to whether they used no frame, one frame (single), two frames (paired), or three or four frames (multiple). Table 8 presents the frequencies and percentages of the four categories of PIs leadership style. Team members rated five PIs (13.2\%) as not consistently using any frames thus having a no frame leadership style. They indicated that only one PI used a single frame leadership style; 13.2 percent $(n=5)$ used a paired frame leadership style; and a majority $(71.1 \%, \mathrm{n}=27)$ used a multi-frame leadership style. Principal investigators in this study were more likely to adopt a multi-frame leadership style rather than the no, single, or paired styles. 
Running Head: PI LEADERSHIP STYLE AND COLLABORATION

Table 8

Frequency Distribution by Frame Pattern

\begin{tabular}{lccc} 
Category/Pattern & F & \% category & $\%$ total \\
\hline No frame & 5 & $100.0 \%$ & $13.2 \%$ \\
Single frame & & & \\
Structural & & & $0.0 \%$ \\
Human Resource & 0 & $0.0 \%$ & $2.6 \%$ \\
Political & 1 & $100.0 \%$ & $0.0 \%$ \\
Symbolic & 0 & $0.0 \%$ & $0.0 \%$ \\
Total & 0 & $0.0 \%$ & $2.6 \%$ \\
& 1 & $100.0 \%$ & \\
Paired-frame & & & $7.9 \%$ \\
Structural/human resource & & & $0.0 \%$ \\
Structural/political & 3 & $60.0 \%$ & $0.0 \%$ \\
Structural/symbolic & 0 & $0.0 \%$ & $2.6 \%$ \\
Human resource/political & 0 & $0.0 \%$ & $2.6 \%$ \\
Human resource/symbolic & 1 & $20.0 \%$ & $0.0 \%$ \\
Political/symbolic & 1 & $20.0 \%$ & $13.2 \%$ \\
Total & 0 & $0.00 \%$ &
\end{tabular}

Multi-frame

Structural/human resource/political

Structural/human resource/symbolic

Structural/political/symbolic

Human resource/political/symbolic

Structural/human resource/political/symbolic

Total

27

$7.4 \%$

$3.7 \%$

$3.7 \%$

$11.1 \%$

$74.1 \%$

$100 \%$

$71.1 \%$

Research question 2. What is the collaboration satisfaction of interdisciplinary research teams?

Collaboration satisfaction was determined by using an eight-item subscale on the Collaboration and Transdisciplinary Integration Survey. Team members' ratings of 4.0 or higher indicated their satisfaction with collaboration as good to excellent. Table 9 presents the frequency distribution of team means on the collaboration satisfaction scale of the survey. The 
Running Head: PI LEADERSHIP STYLE AND COLLABORATION

overall mean was 4.06 with a standard deviation of 0.43 . Team means ranged from $2.92(\mathrm{SD}=$ $0.50)$ to $4.81(\mathrm{SD}=0.40)$. Nearly 53 percent of teams identified that the satisfaction with collaboration was good to excellent.

Table 9

Frequency Distribution for Team Means on the Collaboration Satisfaction Scale $(n=38)$

Team Mean Score Range $\quad$ Frequency Percent

\begin{tabular}{lcc}
\hline$\leq 2.99$ & 1 & $2.6 \%$ \\
$3.00-3.99$ & 17 & $44.7 \%$ \\
$4.00-4.99$ & 20 & $52.6 \%$
\end{tabular}

Note. The response scale for collaboration satisfaction: $1=$ inadequate, $2=$ poor, $3=$ satisfactory, $4=$ good, and $5=$ excellent.

Figure 5 reports the frequency distribution for each item on the collaboration satisfaction scale of the Collaboration and Transdisciplinary Integration Survey. More than $70 \%$ of respondents rated their satisfaction as good to excellent in the areas of accepting new ideas $(\mathrm{n}=$ $135)$, communicating with each other $(\mathrm{n}=124)$, capitalizing on each other's strengths $(\mathrm{n}=138)$, structuring within the group $(n=124)$, involving researchers from other institutions $(n=120)$ and involving team members from diverse disciplines $(n=129)$. Approximately $65 \%$ rated their resolution of conflicts $(\mathrm{n}=114)$ and meeting productivity $(\mathrm{n}=108)$ as satisfactory to good. Although most respondents seemed satisfied with their collaboration, upwards of $7 \%$ expressed their experience as inadequate or poor in the areas of acceptance of new ideas $(n=5)$, communication $(n=9)$, strengths utilization $(n=5)$, structure/organization $(n=11)$, conflict resolution $(n=10)$, and inter-institutional involvement $(n=11)$ while more than $8 \%$ expressed dissatisfaction with the productivity of collaborative meetings $(n=14)$. 
Running Head: PI LEADERSHIP STYLE AND COLLABORATION

Figure 5

Frequency Distribution for Item Responses on the Collaboration Satisfaction Scale

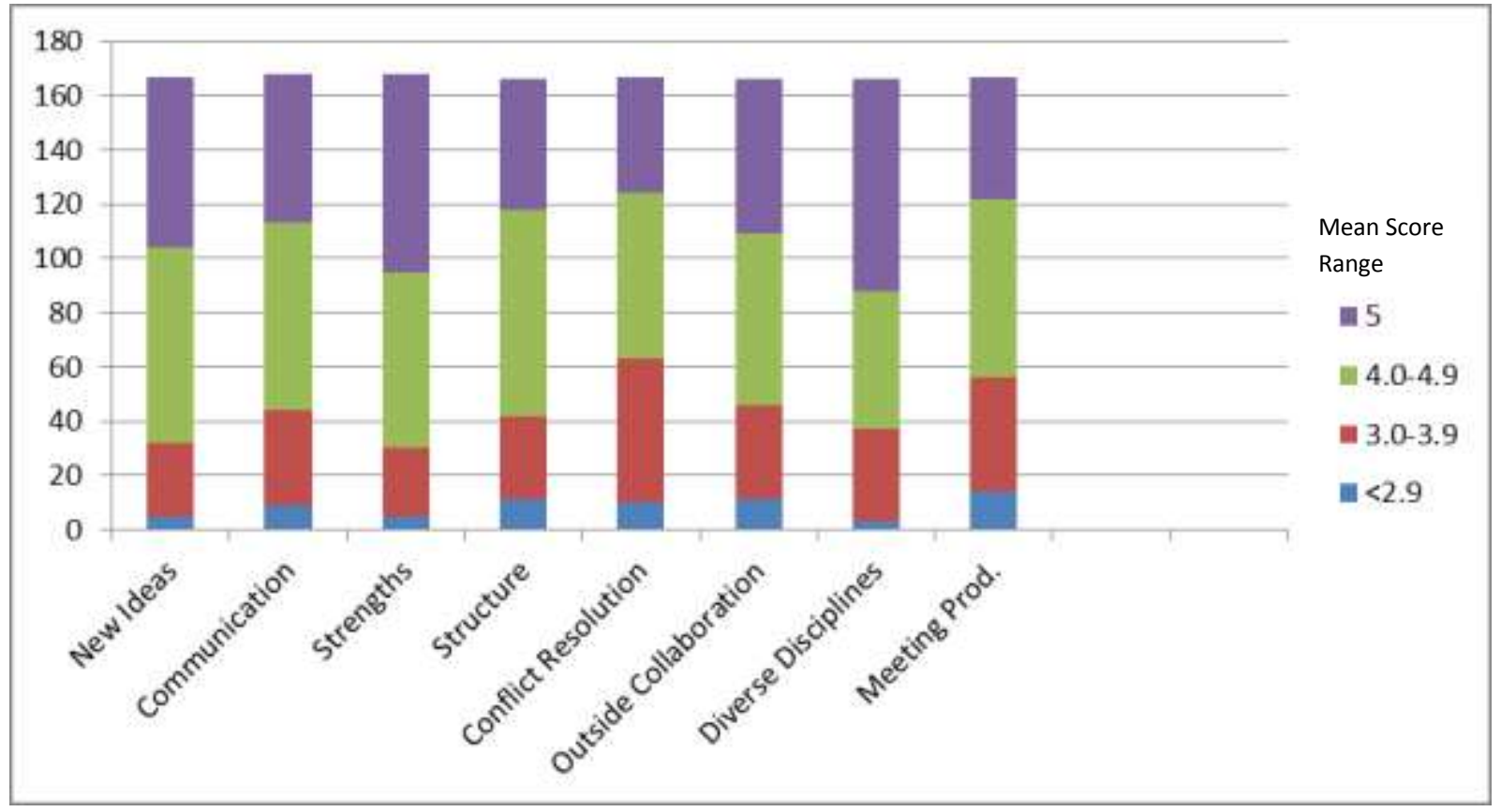

Note. The response scale for collaboration satisfaction: $1=$ inadequate, $2=$ poor, $3=$ satisfactory, $4=$ good, and $5=$ excellent.

Research question 3. Is there a statistically significant difference in the collaboration satisfaction scores of research team members who have principal investigators with different dominant leadership frames (structural, human resource, political, and symbolic)?

To answer this question the individual team member collaboration satisfaction scores were compared between those who had PIs that fell into each of the dominant frame categories (structural, human resource, political, and symbolic). Table 10 presents the means and standard deviations of collaboration satisfaction by category of dominant leadership frames, as well as the results of the one-way ANOVA with Post-Hoc analysis. The mean collaboration satisfaction reported by team members with PIs classified as using the symbolic frame as their dominant frame was the highest $(M=4.35, S D=0.71)$. This was followed by the structural frame $(M=$ 
Running Head: PI LEADERSHIP STYLE AND COLLABORATION

4.10, $\mathrm{SD}=0.74)$, the human resource frame $(\mathrm{M}=4.07, \mathrm{SD}=0.63)$, and finally the political frame $(\mathrm{M}=3.71, \mathrm{SD}=0.67)$. With regard to collaboration satisfaction, the ANOVA identified that team members' reports had a small statistically significant effect between the dominant frames, $F(3,166)=4.310, p<.05, \omega=0.23$. Because the number of dominant frames had more than two levels, post hoc tests were required to determine which group means were significantly different from any of the other group means. Multiple comparison tests were conducted using the Tukey's Honestly Significant Difference test (HSD). Based on these calculations the political frame differed significantly $(p<.05)$ from both the symbolic and human resource frames.

Table 10

Difference in Collaboration Satisfaction by Category of Dominant Leadership Frame

\begin{tabular}{|c|c|c|c|}
\hline Dominant Frame & Mean & $\begin{array}{l}\text { Standard } \\
\text { Deviation }\end{array}$ & $\begin{array}{l}\text { Tukey HSD } \\
\text { Post-HOC }\end{array}$ \\
\hline
\end{tabular}

Structural $(\mathrm{n}=42)$

4.10

0.74

Human Resource $(\mathrm{n}=75)$

4.07

0.63

$*$

Political $(\mathrm{n}=36)$

3.71

0.67

Symbolic $(\mathrm{n}=17)$

4.35

0.71

$* p<.05$ significantly different from the political frame

Research question 4. Is there a statistically significant difference in the collaboration satisfaction of research team members who have principal investigators with different leadership styles (no, single, paired, or multi-framed)?

To answer this question the means for individual collaboration satisfaction scores were compared between PIs with different leadership styles (no, paired, and multi-framed). Table 11 presents the means and standard deviations of collaboration satisfaction by category of 


\section{Running Head: PI LEADERSHIP STYLE AND COLLABORATION}

leadership style, as well as the results of the one-way ANOVA with Post-Hoc analysis. There was only one leader with a single frame style and only three members on the team so this team's data was excluded from the analysis. The mean collaboration satisfaction reported by team members with PIs classified as multi-frame leaders was the highest $(\mathrm{M}=4.12, \mathrm{SD}=0.68)$. This was followed by paired frame leaders $(\mathrm{M}=3.87, \mathrm{SD}=0.86)$ and no frame leaders $(\mathrm{M}=3.62, \mathrm{SD}$ $=0.51)$. With regard to collaboration satisfaction, the ANOVA identified that team members' reports had a small statistically significant effect between the leadership styles, $F(2,164)=$ $5.276, p<.05, \omega=0.22$. Because the number of styles had more than two levels, post hoc tests were required to determine which group means were significantly different from any of the other group means. Multiple comparison tests were conducted using the Tukey's Honestly Significant Difference test (HSD). Based on these calculations there was a significant difference $(p<.05)$ between the means for leaders demonstrating the multi-framed style and those with no frame style. The single frame leader was not included in the ANOVA as there was only one leader with three respondents on the team; this team's data was excluded from the analysis. 
Running Head: PI LEADERSHIP STYLE AND COLLABORATION

Table 11

Difference in Collaboration Satisfaction by Category of Leadership Style

Leadership Style

Mean

Standard

Deviation

Tukey HSD

Post-Hoc

No $(\mathrm{n}=20)$

3.62

0.51

Paired $(\mathrm{n}=18)$

3.87

0.86

$\operatorname{Multi}(\mathrm{n}=129)$

4.12

0.68

$*$

$* p<.05$ significantly different from the no frame style

Research question 5. How does the leadership style of principal investigators vary by demographic variables of gender, length of time as principal investigator (less than 3 years, 4 to 5 years, and longer than 6 years), and the size of research team (the number of team members is less than 5 , between 6 and 10, and greater than 11)?

In this data set a majority of team members identified their leaders as experienced and demonstrating a multi-frame style. This resulted in an insufficient sample size for chi-square analysis so the question could only be answered descriptively. Tables 12, 13, and 14 provide detailed data by style for gender and years of experience for the PIs and size of the research team. 
Running Head: PI LEADERSHIP STYLE AND COLLABORATION

Table 12

Gender * Style Crosstabulation

\begin{tabular}{lccc}
\hline \multirow{2}{*}{ Style } & \multicolumn{2}{c}{ Gender } & Total \\
& Female & Male & \\
\hline No & 1 & 4 & 5 \\
Single & 1 & 0 & 1 \\
Paired & 2 & 3 & 5 \\
Multi & 12 & 15 & 27 \\
\hline
\end{tabular}

Table 13

Time as a Principal Investigator * Style Crosstabulation

\begin{tabular}{lcccc}
\hline Style & \multicolumn{2}{c}{ Total } \\
& $\leq 3$ Years & $\begin{array}{c}\text { Time } \\
4-5 \text { Years }\end{array} 2$ Years & \\
No & 0 & 0 & 5 & 5 \\
Single & 0 & 0 & 1 & 1 \\
Paired & 1 & 0 & 4 & 5 \\
Multi & 5 & 4 & 18 & 27 \\
\hline
\end{tabular}


Running Head: PI LEADERSHIP STYLE AND COLLABORATION

Table 14

Size of the Research Team * Style Crosstabulation

Style

Size of Team

Total $\leq 5$ Members 6-10 Members $\geq 11$ Members

$\begin{array}{lcccc}\text { No } & 0 & 2 & 3 & 5 \\ \text { Single } & 0 & 1 & 0 & 1 \\ \text { Paired } & 1 & 4 & 0 & 5 \\ \text { Multi } & 5 & 13 & 9 & 27\end{array}$

These tables highlighted the dominant characteristics of these teams. Team members identified that 22 PIs (57.9\%) were male and 16 (42.1\%) were female. Of the leaders who demonstrated a multi-frame style, 12 were female and 15 were male. In terms of experience, the teams reported that nearly $75 \%$ had served as a PI for more than six years and more than half $(52.6 \%)$ of these interdisciplinary teams were comprised of six to ten members.

\section{Summary}

This chapter reported the results of the data analysis for leadership style of PIs of interdisciplinary research teams in academic health science centers and the collaboration satisfaction of their team members. Before data collection could begin, the accessible population had to be identified through the use of a team identification process detailed above. This resulted in the identification of 100 interdisciplinary research teams made up of 631 individuals at eight institutions. The data were then collected using an online tool that included a basic demographic questionnaire, Bolman and Deal's Leaderships Orientation (others), and the Collaboration and Transdisciplinary Integration Survey. A total of 236 individuals representing 81 teams completed 


\section{Running Head: PI LEADERSHIP STYLE AND COLLABORATION}

the survey. The valid responses used for analysis included 170 individuals from 38 teams at 7 institutions. The individual response rate was $37.4 \%$ representing $81 \%$ of the teams asked to participate. Of those, $72 \%$ of the individuals and $46.9 \%$ of the teams were included in the analyzed data set.

Five predefined research questions were used to guide the data analysis for this study. The statistical procedures included mean, standard deviation, and ANOVA. There was an insufficient sample size to conduct the planned chi-square analysis. An alpha level of .05 was the criterion level of significance set for this data analysis.

The first task was to determine the leadership styles of PIs. Team members identified that the PIs of these interdisciplinary teams used all of the frames, but were more likely to use the human resource and structural frames. The pattern of frame use resulted in the identification that PIs were more likely to adopt a multi-frame leadership style rather than the no, single, or paired styles.

The second undertaking was the identification of collaboration satisfaction for each of the teams. Team members' ratings of 4.0 or higher indicated their satisfaction with collaboration was good to excellent. The overall mean was $4.06(\mathrm{SD}=0.43)$. Team scores for satisfaction ranged from a mean of $2.92(\mathrm{SD}=0.50)$ to a high of $4.81(\mathrm{SD}=0.40)$. Nearly 53 percent of teams identified that the satisfaction with collaboration was good to excellent.

Next the determination as to whether there was a statistically significant difference in collaboration satisfaction scores for teams led by PIs with differing dominant frame use was calculated. The mean of collaboration satisfaction reported by team members with PIs classified as using the symbolic frame as their dominant frame was the highest $(\mathrm{M}=4.35, \mathrm{SD}=0.71)$. This was followed by the structural frame $(M=4.10, S D=0.74)$, the human resource frame $(M=$ 


\section{Running Head: PI LEADERSHIP STYLE AND COLLABORATION}

$4.07, \mathrm{SD}=0.63)$, and finally the political frame $(\mathrm{M}=3.71, \mathrm{SD}=0.67)$. With regard to collaboration satisfaction, the ANOVA identified that team members' reports had a small statistically significant effect between the dominant frames, $F(3,166)=4.310, p<.05, \omega=$ 0.23. The political frame differed significantly $(p<.05)$ from both the symbolic and human resource frames.

This was followed by the determination as to whether there was a statistically significant difference in collaboration satisfaction scores for teams led by PIs with differing leadership styles. The mean of collaboration satisfaction reported by team members with PIs classified as multi-frame leaders was the highest $(\mathrm{M}=4.12, \mathrm{SD}=0.68)$. This was followed by paired frame leaders $(\mathrm{M}=3.87, \mathrm{SD}=0.86)$ and no frame leaders $(\mathrm{M}=3.62, \mathrm{SD}=0.51)$. With regard to collaboration satisfaction, the ANOVA identified that team members' reports had a small statistically significant effect between the leadership styles, $F(2,164)=5.276, p<.05, \omega=0.22$. There was a significant difference $(p<.05)$ between the means for leaders demonstrating the multi-frame style and those with no frame style.

Finally, an analysis of how leadership style of PIs varied by the demographic variables of gender, length of time as a PI, and size of team was planned, but in this data set a majority of team members identified their leaders as experienced and demonstrating a multi-framed style. This resulted in an insufficient sample size for chi-square analysis so these differences were defined descriptively. The team members identified that 22 PIs (57.9\%) were male and 16 $(42.1 \%)$ were female and more than half $(52.6 \%)$ led teams comprised of six to ten members. The teams also reported that this group of research leaders were experienced as nearly $75 \%$ had served as a PI for more than six years. 


\section{Running Head: PI LEADERSHIP STYLE AND COLLABORATION}

This summarizes the major findings of this study. A further discussion of these finding will be covered in Chapter 5, along with conclusions and recommendations/implications for future research. 


\section{Chapter 5}

\section{Conclusions and Recommendations}

This chapter summarizes the research study, discusses the major findings and their relationships to the literature, identifies potential applications, and recommends areas for additional research as it relates to leadership of interdisciplinary research teams in academic health science centers. The first section provides an overview of the problem, purpose of the study, and a review of the methodology. The second section discusses the major findings, their relationship to the literature, and potential applications within the framework of the five research questions and the chapter closes with a description of further research possibilities.

\section{Study Overview}

In today's academic institutions the growth of the research mission is complicated by the pressure for increased research funding in a shrinking economy. Principal investigators (PIs) must compete in an extramural funding battle that requires innovative approaches and the use of interdisciplinary teams. The National Institutes of Health (grants.nih.gov) acknowledge that new breakthroughs depend on the work of integrated teams of scientists and identify this type of work as inherently difficult. A number of funding agencies, particularly federal agencies, are now requiring interdisciplinary collaboration for funded projects.

As a result of this changing climate, the area of team science, that is, investigations that study how research teams interact and the significance of this, is an emerging area of study. Robert Croyle (2008), an official at the National Cancer Institute, advocates for further development of the science of team science. Integrated teams working on real world problems are becoming the standard and there is a clear need for a scientific approach to evaluation and impact studies. This research contributes to the new area of team science by exploring both 


\section{Running Head: PI LEADERSHIP STYLE AND COLLABORATION}

collaboration and leadership in interdisciplinary teams. The leadership framework is based on Bolman and Deal's (1984) four frame model. Increasing knowledge of the relationship of both leadership and collaboration satisfaction results in a better understanding of the phenomena of coming together to create an organizational culture where collaboration is both encouraged and reinforced.

Using the Bolman and Deal framework, this study identified dominant frame use and leadership style of PIs leading interdisciplinary research teams at academic health science centers. Additionally the study measured the satisfaction levels of members of collaborative research teams to discern if there was a difference in satisfaction related to dominant frame use and the leadership style of the PIs. The two measured variables were the leadership style/frame use of the PI and the satisfaction of interdisciplinary team members. The independent variable was categorical while the dependent variable was quantitative. In addition, the study provided descriptive statistics regarding the potential confounding variables of PI gender, PI experience (less than three years, four to five years, and longer than six years), and research team size (less than five members, six to ten members, and greater than ten members). This study utilized the causal-comparative research design because the goal was to determine if there was an effect of leadership style/frame use on satisfaction.

In order to identify members of teams, funded PIs at eight institutions were contacted and asked to complete a Team Identification Form. Members of interdisciplinary teams identified by the PIs were then surveyed using an online instrument that included assessment questions from the Demographic Questionnaire, Bolman and Deal Leadership Orientations (Others) Survey, and Collaboration and Transdisciplinary Integration Survey. Data collected from the surveys were 
Running Head: PI LEADERSHIP STYLE AND COLLABORATION

analyzed using the Statistical Package for the Social Scienes, SPSS 20, and an alpha level of .05 was the level of significance for all statistical computations.

\section{Discussion and Application of the Findings}

The results discussed in this section are based on answers to the online surveys completed by members of interdisciplinary research teams; a detailed description of the analysis was covered in Chapter 4. A discussion of the significant results, how they relate to the current literature, and potential applications are organized around the five research questions.

Research question 1. What are the leadership styles (as measured by the frames) of the principal investigators of interdisciplinary research teams?

In this study, team members identified that the PIs used all four of the frames (structural, human resource, political and symbolic) defined by Bolman and Deal (1991, 2003), but were most likely to use the human resource and structural frames. The human resource frame had the highest mean $(M=4.25, \mathrm{SD}=0.46)$, followed by the structural frame $(\mathrm{M}=4.17, \mathrm{SD}=0.46)$ and the symbolic frame $(\mathrm{M}=4.14, \mathrm{SD}=0.40)$. The political frame had the lowest mean $(\mathrm{M}=4.12$, $\mathrm{SD}=0.42$ ). This is similar to other studies completed in higher education; several studies (Bethel, 1998, Borden, 2000, Cantu, 1997, Chang, 2004, Mosser, 2000, and Small 2002) identified the predominant frame as human resource. In addition, Mosser (2000), Small (2002), and Chang (2004) discovered that the structural frame was the secondary frame used by department chairs, while Cantu (1997) identified the political and Borden (2000) listed the symbolic as the secondary frames in their studies. It is not surprising that leaders of interdisciplinary teams were characterized by their followers as most likely using the human resource and structural frames. 


\section{Running Head: PI LEADERSHIP STYLE AND COLLABORATION}

Bolman and Deal's $(1991,2003)$ underlying theoretical framework identified that leaders who use the human resource frame focus on harmonious relationships, consensus decision making, satisfaction, motivation, human needs, working together, and communication; these leaders view staff members as primary resources. Principal investigators of interdisciplinary research teams must bring together team members from various backgrounds; they are called upon to facilitate understanding, build bridges, motivate, empower, listen, exchange information, maintain balance, keep people involved, and promote participation within the group while also aiding in the individual growth and development of team members. Leaders who approach teams using the human resource frame meet many of the needs of their team members and more easily facilitate interdisciplinary research.

When coupling the human resource and structural frames, strong leadership emerges.

Leaders who use the structural frame set clear, measurable goals, develop centralized communication systems, and focus on policy, efficiency, equity, knowledge, skill, and products (Bolman and Deal, 1991, 2003). Those leading interdisciplinary research teams are required to set goals with measurable outcomes, focus on grant deliverables, set rules, define roles, coordinate resources, transmit facts and information, structure decision making processes, and realign goals to complete various tasks. Use of the structural frame increases a principal investigator's ability to organize a team with differing backgrounds and improve their efficiency by setting up clear processes and expectations.

The interplay of this frame data allowed the investigator to determine the leadership style of PIs of interdisciplinary research teams. The team members' ratings of the PIs were analyzed according to whether they used no frame, one frame (single), two frames (paired), or three/four frames (multiple). Team members rated five PIs (13.2\%) as having a no frame leadership style, 


\section{Running Head: PI LEADERSHIP STYLE AND COLLABORATION}

one as single frame (2.6\%), five as paired frame (13.2\%), and 27 as multi-frame $(71.1 \%)$. This pattern of frame use resulted in the identification that PIs in this study were more likely to adopt a multi-frame leadership style. This is a somewhat surprising result based on other leadership studies using this conceptual framework. In previous studies conducted in higher education, Borden (2000) and Turley (2002) found little less than half of area campus administrators and health science directors characterized as multi-frame while Mosser (2000) and Small (2002) identified nearly one-third of departmental chairs as multi-frame and Chang found that only $15 \%$ were multi-frame. The gap in results is even more dramatic when considering Bensimon's (1989) premier work in higher education leadership studies where only $25 \%$ of presidents were classified as using multiple frames. The use of multiple frames allows leaders to view the organization and issues they encounter through different lenses; Bolman and Deal (2003) hypothesized that this approach improves leadership and results in increased organizational efficiency. Team science is a complicated endeavor where there are often intrapersonal and interpersonal struggles, conflict among team members, and even institutional angst. In Kessel and Rosenfield's (2008) work with team science they identified a number of constraining factors including competitiveness between team members, tension between solo and collaborative science, power differentials, problems with shared credit, and institutional rigidity. Team science leaders must effectively navigate the dynamics of their teams, institutions, and funding agencies and the ability to look at situations from a variety of perspectives (multiple frames) should theoretically be of benefit. Although this result differs from other leadership studies in higher education, it is important to note that these teams were led by researchers who were successful in obtaining federal funding and that this research finding may be related to the selection bias. 


\section{Running Head: PI LEADERSHIP STYLE AND COLLABORATION}

In sharp contrast to multi-framed leaders is that of the no frame style. In this study only $13.2 \%$ were identified in this category. The results of leadership studies in higher education for this frame range from none (Bensimon, 1987) to more than 56\% (Chang, 2004). The theoretical framework indicates that leaders with a no frame style may find it difficult to manage complex situations (Bolman \& Deal, 2003). As identified above leaders conducting funded team science might then be challenged when forced to deal with the many constraining factors facing them.

Finally in this study, there were few leaders utilizing the single $(2.6 \%)$ and paired frame styles (13.2\%). In Bensimon's (1989) pioneering work she found nearly $41 \%$ of presidents were single frame while other studies ranged from 15\% (Chang, 2004) to just over 20\% (Small, 2002). For the paired frame the range was $11 \%$ (Small, 2002) to 34\% (Bensimon, 1989). Theoretically as leaders increase the number of frames they utilize, their efficiency and effectiveness also increases (Bolman \&Deal, 2003).

The science of team science is an emerging field and this is the first study to characterize the style of leaders using the Bolman and Deal framework. Gray (2008) completed a literature review and asserted that successful interdisciplinary research team leaders needed to engage in cognitive, structural, and processual behaviors. This study demonstrated that leaders of these research teams demonstrated these behaviors and were classified by their followers as using multiple frames.

Research question 2. What is the collaboration satisfaction of interdisciplinary research teams?

Collaboration satisfaction was determined by using an eight-item subscale on the Collaboration and Transdisciplinary Integration Survey. Team members' ratings of 4.0 or higher on a 5.0 scale indicated their satisfaction with collaboration as good to excellent. The overall 


\section{Running Head: PI LEADERSHIP STYLE AND COLLABORATION}

mean for collaboration satisfaction was 4.06 with a standard deviation of 0.43 . Nearly 53 percent of teams identified that their overall satisfaction with collaboration was good to excellent. In this study the team members reported overall satisfaction with the collaborative process.

Although most respondents expressed overall satisfaction with their collaboration, when breaking down the subscale and conducting an item analysis, the areas of team meeting productivity, increased collaboration with other institutions, structure/organization, conflict resolution, communication, acceptance of new ideas, and strengths utilization rose to the surface as potential areas of improvement. In a comprehensive review of the literature, Lakhani, Benzies, and Hayden (2012) identified seven needed characteristics for successful collaboration: clear purpose, defined goals, effective leadership, communication, cohesion, mutual respect, reflection. This list of attributes parallels the areas of need identified on the collaboration satisfaction subscale. The need for sharpening skills through increased training and/or interdisciplinary experiences is evident.

At the end of 2007, the National Institutes of Health developed the Interdisciplinary Research Consortia as a means of standardizing training and evaluation while also addressing and breaking down institutional barriers (www.nih.gov/news/pr/sep2007); this research endeavor mandated training initiatives for all levels of investigators: undergraduate, graduate, and postdoctorate. Building on this initiative while further developing, expanding, and prioritizing clinical and translational science served to drive the focus on team science. As a result, researchers and practitioners developed a number of training resources. One of these tools, Facilitating Interdisciplinary Research and Education: A Practical Guide (Derrick, FalkKrzesinski, and Roberts, 2012), resulted from a 2011 workshop entitled "Science on FIRE: Facilitating Interdisciplinary Research and Education." In addition, the National Cancer Institute 


\section{Running Head: PI LEADERSHIP STYLE AND COLLABORATION}

developed an online Team Science Toolkit (http://teamsciencetoolkit.cancer.gov) and the Northwestern University Clinical and Translational Science Institute created COALESCE, an interactive series of online learning modules (Spring, Moller, and Falk-Krzesinski, 2011). Although the overall collaboration scores for this study were high, participants still indicated areas for potential improvement. The collaboration satisfaction subscale results indicated that scores could improve, especially in the areas of conflict resolution and meeting productivity. Implementation of workshops, online training modules, or mentoring sessions that focus on these areas could enhance team satisfaction; all of the resources listed above could be utilized to improve the skills of both leaders and team members who collaborate.

The findings of this study indicate that the most satisfied team members are led by those who are multi-frame and include use of the symbolic frame. As a means of incorporating continuous quality improvement, teams could measure satisfaction as part of an internal audit of functioning. This information could then be included in progress reports to funders, as well as future grant applications. Additionally, leaders could proactively address the issue of conflict resolution by creating team charters that establish processes for addressing conflict and encouraging open communication; these documents could also serve to strengthen grant applications, as well as improving team functioning.

The Collaboration and Transdisciplinary Integration Survey was developed and tested (Masse et al., 2008) with the Transdisciplinary Tobacco Use Research Centers. In the initial testing of the instrument, team members expressed a similar level of satisfaction; overall team scores ranged from 3.45 to 4.47 (satisfactory to good) on a five point scale. This is the only other published study utilizing this instrument. 


\section{Running Head: PI LEADERSHIP STYLE AND COLLABORATION}

Research question 3. Is there a statistically significant difference in the collaboration satisfaction scores of research team members who have principal investigators with different dominant leadership frames (structural, human resource, political, and symbolic)?

The highest mean score for collaboration satisfaction was recorded for PIs using the symbolic frame as their dominant frame $(\mathrm{M}=4.35, \mathrm{SD}=0.71)$. This was followed by the structural frame $(\mathrm{M}=4.10, \mathrm{SD}=0.74)$, the human resource frame $(\mathrm{M}=4.07, \mathrm{SD}=0.63)$, and finally the political frame $(\mathrm{M}=3.71, \mathrm{SD}=0.67)$. An analysis of variance identified that team members' reports identified a small statistically significant effect between the dominant frames, $F(3,166)=4.310, p<.05, \omega=0.23$. The political frame differed significantly $(p<.05)$ from both the symbolic and human resource frames.

Bolman and Deal's $(1991,2003)$ underlying theoretical framework identified that leaders who use the symbolic frame create a vision, draw on history, provide a shared sense of mission, develop a culture that promotes identity, and fosters a community that overcomes uncertainty. Principal investigators of interdisciplinary research teams must provide meaning, build consensus, and appeal to shared values in order to overcome constraining factors and facilitate interdisciplinary team research. It is not surprising then that leaders characterized as using the symbolic frame had the highest collaboration satisfaction scores. In addition, the largest differences were seen between leaders whose dominant frames were symbolic and political. According to Bolman and Deal (2003), political leaders are strongest in the areas of power, bargaining, influence, and coalition building. Although these skills are valuable and may enable a PI to navigate institutional and funding agency requirements, they are likely to be viewed as less satisfactory in small group interactions and management of a team. 


\section{Running Head: PI LEADERSHIP STYLE AND COLLABORATION}

The other significant difference was between the human resource frame and the political frame. As stated earlier in the discussion, Bolman and Deal $(1991,2003)$ identified that leaders who use the human resource frame focus on harmonious relationships, consensus decision making, satisfaction, motivation, human needs, working together, and communication. Again when compared to the skills of leaders using the political frame, a focus on staff as a primary resource is likely viewed as more satisfactory to team members and the results of this study confirmed this.

A potential application of these findings is training and continuing education for those leading interdisciplinary research teams. Leadership seminars for PIs could include information on the symbolic frame and transformational leadership where emphasis is placed on communicating a vision and tying the work one is engaged in to a bigger picture; helping team members understand their connections to the institutional mission and scientific significance of their work may increase collaboration satisfaction and group cohesion. Additionally, measuring leadership and providing feedback to PIs on their dominant frames and style would allow them to identify weaknesses; they could then address this through training and/or choice of coinvestigators with complementary styles.

Research question 4. Is there a statistically significant difference in the collaboration satisfaction of research team members who have principal investigators with different leadership styles (no, single, paired, or multi-framed)?

The highest mean score for collaboration satisfaction was recorded for PIs identified as multi-frame $(M=4.12, S D=0.68)$. This was followed by paired frame leaders $(M=3.87, S D=$ $0.86)$ and no frame leaders $(\mathrm{M}=3.62, \mathrm{SD}=0.51)$. There was only one leader with a single frame style and only three members on the team so this team's data was excluded from the analysis. An 
Running Head: PI LEADERSHIP STYLE AND COLLABORATION

analysis of variance identified that team members' reports were statistically different between the styles $(F(2,164)=5.276, p<.05, \omega=0.22)$ and multiple comparison tests showed there was a significant difference in the means between the multi-frame style and the no frame style. As stated earlier, the use of multiple frames allows leaders to view the organization and issues they encounter through different lenses; Bolman and Deal (2003) hypothesized that this approach improves leadership and results in increased organizational efficiency. Team science is a complicated endeavor where there are often intrapersonal and interpersonal struggles, conflict among team members, and even institutional angst. In Kessel and Rosenfield's (2008) work with team science they identified a number of constraining factors including competitiveness between team members, tension between solo and collaborative science, power differentials, problems with shared credit, and institutional rigidity. Team science leaders must effectively navigate the dynamics of their teams, institutions, and funding agencies and the ability to look at situations from a variety of perspectives (multiple frames) should theoretically be of benefit; this study demonstrated that multi-frame leaders have significantly higher collaboration satisfaction scores than leaders utilizing a no frame style. Although this result differs from other leadership studies in higher education, it is important to note that these teams were led by researchers who were successful in obtaining federal funding and that this research finding may be related to the selection bias.

Even though the majority of leaders in this study were multi-frame, there were $11 \mathrm{NIH}-$ funded researchers identified as using the no, single, or paired frame styles. Leaders, regardless of style could enhance grant applications by providing evidence of a team's readiness for collaboration through description of his/her leadership style, communication processes, and use of tools that measure readiness and continuity of collaboration. 


\section{Running Head: PI LEADERSHIP STYLE AND COLLABORATION}

Research question 5. How does the leadership style of principal investigators vary by gender, experience, and size of the team?

An analysis of how leadership style of PIs varied by the demographic variables of gender, length of time as a PI, and size of team was planned, but in this data set a majority of team members identified their leaders as experienced and multi-framed. This resulted in an insufficient sample size for chi-square analysis so these differences were defined descriptively.

Team members identified 22 PIs (57.9\%) as male and $16(42.1 \%)$ as female. In other completed studies using the Bolman and Deal instrument, male leaders significantly outnumbered females (Bensimon, 1989, Chang, 2004), except in the studies exploring leadership in nursing programs (Mosser, 2000, Small 2002). A sample with over $40 \%$ of female research team leaders is a surprising finding. In 2013, the National Science Foundation identified that women were underrepresented in the fields of science, technology, engineering, and mathematics. In the last 20 years the percentage of women working as full time, full professors in research institutions has doubled, but currently rests at just over 20\% (NSF, 2013).

A number of studies have explored the question of gender diversity (Baugh \& Graen, 1997; Ely \& Thomas, 2001; Joshi \& Roh, 2009; Mannix \& Neale, 2005; Myaskovsky, Unikel, \& Dew, 2005; Pelled, 1996; Webber \& Donahue, 2001; Woolley, Chabris, Pentland, Hashmi, \& Malone, 2010) and concluded that increased representation of women on teams improved group process. Woolley et al. (2010) and Carli (2010) identified that the presence of women on teams enhanced communication and increased behaviors such as turn taking in conversations and accurate reading of nonverbal cues. In this study the symbolic and human resource frames yielded statistically different satisfaction scores; both of these frames deal with communication processes. Because other researchers concluded that female participation and leadership 


\section{Running Head: PI LEADERSHIP STYLE AND COLLABORATION}

influences team functioning, additional empirical studies are needed to further explore this relationship for interdisciplinary research teams.

In terms of size, more than half $(52.6 \%)$ of the PIs led teams comprised of six to ten members. This was followed by larger teams (31.6\%) comprised of eleven or more members and small teams (15.8\%) with five or less participants.

Finally, the teams reported that this group of research leaders were experienced as nearly $75 \%$ had served as a PI for more than six years. This is an expected finding since all of the investigators were NIH-funded and leading interdisciplinary research teams. This type of research tends to be highly competitive and experience and publication record contribute to the overall impact score of grants. This is an expected finding based on career trajectory and the time needed to build relationships to assemble a competitive grant.

Incidental finding. Only one of the eight institutions contacted could identify the funded investigators leading interdisciplinary research teams. Since there is a move at the national level to fund interdisciplinary teams, a grant application that includes language regarding an institution's commitment to team science and track record could enhance the resources section of $\mathrm{NIH}$ and foundation applications. This incidental finding is significant and could lead to changes in processes in the Offices of Sponsored Programs.

\section{Further Studies}

Most of the recent studies in team science focus on measuring the effectiveness (outcome measures) of teams while this research contributes to the understanding of context; there continues to be a call for studies regarding contextual issues to address gaps in the current literature. Since this is the first study to explore the leadership of interdisciplinary research teams using the Bolman and Deal Leadership Orientations (Others) instrument additional studies are 


\section{Running Head: PI LEADERSHIP STYLE AND COLLABORATION}

needed to establish if there is a pattern of increased numbers of multi-frame leaders among interdisciplinary research team leaders in other institutions. Building on this model, studies that examine outcomes such as funding levels, funder diversity, and bibliometric measures (number, type, and impact), as well as determining the leadership style of the PI could identify if there is a relationship between leadership and effectiveness in terms of those outcome measures most treasured in the scientific community. In addition to incorporating effectiveness measures into future leadership studies, it is also important to study team dynamics.

This research project did not take into account the role of the follower or the dynamics associated with productive teams where the leader vacillates between the role of leader and follower (shared leadership). Also the study did not measure institutional commitment to interdisciplinary research or ask questions related to tenure, promotion, collegial home, or institutional culture; all of these factors could potentially affect satisfaction with collaboration and team functioning. Mixed method studies that explore these dynamics as well as quantitatively measuring style and satisfaction would significantly contribute to the study of team science.

Additionally, empirical studies are needed to further explore the gender influences for interdisciplinary research teams, both in terms of leadership and membership. With the current data set, one could explore items from the Collaboration and Transdisciplinary Integration Survey in terms of the gender of the research leader and/or the gender of the team member responding. Finally, exploration and isolation of other variables that influence collaboration satisfaction could lead to improved understanding of the dynamics of these teams.

This study contributes to the emerging field of team science. As more resources are awarded to large, diverse scientific teams, there is increased scrutiny and demand for proof that 


\section{Running Head: PI LEADERSHIP STYLE AND COLLABORATION}

this investment results in improved outcomes. Better understanding of how scientific teams work, who leads them, and what factors contribute to successful collaborations will lead to an improved process for determining who receives these awards. This study is one small step toward addressing the gaps in the literature regarding individual factors by qualitatively characterizing leadership of interdisciplinary teams. 
Running Head: PI LEADERSHIP STYLE AND COLLABORATION

\section{References}

Aboelela, S.W., Larson, E., Bakken, S., Carrasquillo, O., Formicola, A., \& Glied, S, et al. (2007). Defining interdisciplinary research: Conclusions from a critical review of the literature. Health Services Research, 42, 329-346. doi:10.1111/j.1475-6773.2006.00621.x

Author unknown. Association of Academic Health Sciences Centers home page. Retrieved from www.aahcdc.org.

Author unknown. Carnegie Foundation for the Advancement of Teaching, basic classification. Retrieved from http://classifications.carnegiefoundation.org/lookup_listings/srp.php?clq $=\{\% 22$ basic2005 _ids\%22\%3A\%2215\%22\}\&limit=0,50.

Author unknown. National Institutes of Health web page. Retrieved from http://grants.nih.gov/grants/guide/pa-files/PA-10-106.html\#SectionII.

Author unknown. National Institutes of Health, NIH news. Retrieved from http://www.nih.gov/news/pr/sep2007/od-06.htm.

Author unknown. National Institutes of Health Research Portfolio Online Reporting Tools. Retrieved from http://projectreporter.nih.gov/reporter.cfm.

Author unknown. National Cancer Institute team science toolkit. Retrieved from http://teamsciencetoolkit.cancer.gov/public/Home.aspx

Author unknown. Science of Team Science conference. Retrieved from http://www.scienceofteamscience.org/.

Bass, B.M. (1981). Stodgill's handbook of leadership. New York: The Free Press.

Bass, B. M. (1990). Handbook of leadership: Theory, research, and managerial applications (3rd ed.) New York: The Free Press. 
Running Head: PI LEADERSHIP STYLE AND COLLABORATION

Baugh, S.G., \& Graen, G.B. (1997). Effects of team gender and racial composition on perceptions of team performance in cross-functional teams. Group \& Organizational Management, 22, 366383. doi: $10.1177 / 1059601197223004$

Bell, T.H. (1982). The federal role in education. Harvard Educational Review, 52, 375-380.

Bellah, R.N., Madsen, R., Sullivan, W.M., Swidler, A., \& Tipton, S.M. (1991). The Good Society. New York: Alfred A. Knopf.

Benne, K.D., \& Sheats, P. (1948). Functional goals of group members. Journal of Social Issues, 4, 41-49. DOI: 10.1111/j.1540-4560.1948.tb01783.x

Bennis, W.G., \& Nanus, B. (1997). Leaders: The strategies for taking charge (2 ${ }^{\text {nd }}$ ed.). New York: Harper \& Row.

Bensimon, E.M. (1989). The meaning of good presidential leadership: A frame analysis (ASHE Higher Education Report). Washington, DC: Association for the Study of Higher Education.

Bethel, C. (1998). The relationship between presidential leadership orientations and organizational effectiveness in bible colleges (Unpublished doctoral dissertation). West Virginia University, Morgantown, WV.

Blake, R.R., \& Mouton, J.S. (1985). The Managerial Grid III. Houston: Gulf.

Boardman, C., \& Bozeman, B. (2004). The NSF engineering research centers and the universityindustry research revolution: A brief history featuring an interview with Erich Bloch. Journal of Technology Transfer, 29, 365-375. doi:10.1023/B:JOTT.0000034128.39526.6b

Boardman, P.C., \& Ponomariov, B.L. (2007). Reward systems and NSF university research centers: The impact of tenure on university scientists' valuation of applied and commercially relevant research. Journal of Higher Education, 78(1), 51-70.

Bolman, L. G., \& Deal, T. E. (1984). Modern approaches to understanding and managing 
Running Head: PI LEADERSHIP STYLE AND COLLABORATION

organizations. San Francisco: Jossey-Bass.

Bolman, L. G., \& Deal, T. E. (1991). Reframing Organizations. San Francisco: Jossey- Bass.

Bolman, L. G., \& Deal, T. E. (1991). Leadership and management effectiveness: A multi-frame, multi-sector analysis. Human Resource Management, 30(4), 509-534.

Bolman, L. G., \& Deal, T. E. (1992). Leading and managing: Effects of context, culture, and gender. Educational Administration Quarterly, 28(3), 314-329.

Bolman, L.G., \& Deal, T.E. (2003). Reframing organizations: Artistry,choice, and leadership ( ${ }^{\text {rd }}$ ed.). San Francisco: Jossey-Bass.

Bolman, L.G. (2008). Research with leadership orientations instruments. Retrieved from www.leebolman.com/orientations.

Borden, M. P. (2000). Leadership orientations of area campus administrators in Florida's state university and community college systems: A frame analysis. Dissertation Abstracts International, 61(10A), 3913.

Borrego, M., \& Newswander, L. (2010). Definitions of interdisciplinary research: Toward graduate-level interdisciplinary learning outcomes. Review of Higher Education, 34(1), 61-84. doi: 10.1353/rhe.2010.0006

Bozeman, B., \& Boardman, C. (2007). Role strain in university research centers. Journal of Higher Education, 78(4), 430-463.

Braxton, J.M., Luckey, W., \& Holland, P. (2002). Institutionalizing a broader view of scholarship through Boyer's four domains (ASHE-ERIC Higher Education Report). Washington, DC: Association for the Study of Higher Education.

Bruhn, J.G. (2000). Interdisciplinary research: A philosophy, art form, artifact, or antidote? Integrative Psychological and Behavioral Science, 35, 58-66. doi: 10.1007/BF02911166 
Running Head: PI LEADERSHIP STYLE AND COLLABORATION

Bunton, S.A., \& Mallon, W.T. (2007). The continued evolution of faculty appointment and tenure policies at U.S. medical schools. Academic Medicine, 82, 281-289. doi: 10.1097/ACM.0b013e3180307e87

Cantu, D. A. (1997). The leadership frames of academic deans randomly selected and nominated as exceptionally effective at public colleges and universities. (Doctoral dissertation, Arkansas State University). Dissertation Abstracts International, 5(03A), 650.

Carli, L.L. (2010). Gender and group behavior. In J. Chrisler \& D. McCreary (Eds.), Handbook of gender research in psychology (pp. 337-358). New York: Springer.

Chang, Tongshan. (2004). Leadership styles of department chairs and faculty utilization of instructional technology (Doctoral dissertation, West Virginia University, Morgantown,

WV). Retrieved from http://etd.wvu.edu.

Clark, Burton. (1985). The school and the university: An international perspective. Berkeley: University of California Press.

Cohen, A.M. (1998). The shaping of American higher education. San Francisco: Jossey-Bass.

Croyle, R.T. (2008). The national cancer institute's transdisciplinary centers initiatives and the need for building a science of team science. American Journal of Preventive Medicine, 35 (S2), 90-93. doi: 10.1016/j.amepre.2008.05.012

Derrick, E.G., Falk-Krzesinski, H.J., \& Roberts, M.R, (Eds). (2012) Facilitating interdisciplinary research and education: A practical guide. Retrieved from http://www.aaas.org/cspsp/interdisciplinary/guide. 


\section{Running Head: PI LEADERSHIP STYLE AND COLLABORATION}

Ely, R.J., \& Thomas, D.A. (2001). Cultural diversity at work: The effects of diversity perspectives on work group processes and outcomes. Administrative Science Quarterly, 46 (2): 229-273. doi: $10.2307 / 2667087$

Falk-Krzesinski, H.J., Boner, K., Contractor, N., Cummings, J., Fiore, S.M., Hall, K.L., Keyton, J., Spring, B., Stokols, D., Trochim, W., \& Uzzi, B. (2010). Advancing the science of team science. Clinical Translational Science, 3(5), 263-266. doi:10.1111/j.1752-8062.2010.00223.x

Falk-Krzesinski, H.J., Contractor, N., Fiore, S.M., Hall, K.L., Kane, C., Keyton, J., Klein, J.T, Spring, B., Stokols, D., \& Trochim, W. (2011). Mapping a research agenda for the science of team science. Research Evaluation, 20(2), 145-158. doi:10.3152/095820211X12941371876580

Feller, I. (2002). New organizations, old cultures: Strategy and implementation of interdisciplinary programs. Research Evaluation, 11, 109-116. doi: 10.3152/147154402781776862

Fiore, S.M. (2008). Interdisciplinarity as teamwork - How the science of teams can inform team science. Small Group Research, 39(3), 251-277. doi: 10.1177/1046496408317797

Fox, M.F., and Faver, C.A. (1984). Independence and cooperation in research: The motivations and costs of collaboration. Journal of Higher Education, 55(3), 347-359.

Gay, L.R., Mills, G.E., \& Airasian, P. (2006). Educational research: Competencies for analysis and applications. Pearson Education: Upper Saddle River, NJ.

Glied, S., Bakken, S., Formicola, A., Gebbie, K., \& Larson, E.L. (2007). Institutional challenges of interdisciplinary research centers. Journal of Research Administration, 38(2), 28-36.

Golde, C.M., \& Gallagher, H.A. (1999). The challenges of conducting interdisciplinary research in traditional doctoral programs. Ecosystems, 2(4), 281-285. doi: 10.1007/s100219900076

Gray, B. (2008). Enhancing transdisciplinary research through collaborative leadership. American Journal of Preventive Medicine, 35(S2), 124-132. doi: 10.1016/j.amepre.2008.03.037 
Running Head: PI LEADERSHIP STYLE AND COLLABORATION

Gumport, P.J. (1988). Curricula as signposts of cultural change. Review of Higher Education, 12, 49-61.

Hackman, M.Z., \& Johnson, C.E. (2004). Leadership: A communication perspective. Long Grove, IL: Waveland Press.

Hafernik, J.J., Messerschmitt, D.S., \& Vandrick, S. (1997). Collaborative research: How and why? Educational Researcher, 26, 31-35. Retrieved from http://www.jstor.org/stable/1176273

Hall, K.L., Feng, A.X., Moser, R.P., Stokols, D., \& Taylor, B. K. (2008). Moving the science of team science forward: Collaboration and creativity. American Journal of Preventive Medicine, 35 (S2), 243-249. doi: 10.1016/j.amepre.2008.05.007

Hall, K.L., Vogel, A.L., Stipelman, B.A., Stokols, D., Morgan, G., \& Gehlert, S. (2012). A fourphase model of transdisciplinary team-based research: goals, team processes, and strategies.

Translational Behavioral Medicine, 2(4), 415-430.

Hart, J., \& Mars, M.M. (2009). Joint appointments and professoriate: Two houses but no home? Innovative Higher Education, 34, 19-32. doi: 10.1007/s10755-008-9092-x

Heberlein, T.A. (1988). Improving interdisciplinary research: Integrating the social and natural sciences. Social Natural Research, 1, 5-16. doi: 10.1080/08941928809380634

Hersey, P., \& Blanchard, K.H. (1996). Management of organizational behavior: Utilizing human resources $\left(7^{\text {th }}\right.$ ed.). Englewood Cliffs, NJ: Prentice-Hall, Inc.

Hoy, W.K., \& Miskel, C.G. (2005) Educational administration: Theory, research, and practice $\left(7^{\text {th }}\right.$ edition.) New York: McGraw-Hill.

Illman, D.L. (2007). Profiles in team science. University of Washington. Retrieved from http://depts.washington.edu/teamsci/pdfs/_TeamScienceComplete_sm.pdf. 


\section{Running Head: PI LEADERSHIP STYLE AND COLLABORATION}

Jeffery, P. (2003). Smoothing the waters: Observations on the process of cross-disciplinary research collaboration. Social Studies of Science, 33(4), 539-562. doi: 10.1177/0306312703334003

Joshi, A., \& Roh, H. (2009). The role of context in work team diversity research: A meta-analytic review. Academy of Management Journal, 52(3): 599-627. doi: 10.5465/AMJ.2009.41331491

Kessel, F., \& Rosenfield, P.L. (2008). Toward transdisciplinary research: Historical and contemporary perspectives. American Journal of Preventive Medicine, 35 (S2), 225-234. doi:

10.1016/j.amepre.2008.05.005

Kezar, A. (2005). Redesigning for collaboration within higher education institutions: An exploration into the developmental process. Research in Higher Education, 46(7), 831-860. doi: $10.1007 / \mathrm{s} 11162-004-6227-5$

Klein, J.T. (2008). Evaluation of interdisciplinary and transdisciplinary research: A literature review. American Journal of Preventive Medicine, 35(2S), 116-123. doi: 10.1016/j.amepre.2008.05.010

Klein, J.T. (2010). Creating interdisciplinary campus cultures: A model for strength and sustainability. San Francisco: Jossey-Boss.

Klein, J.T. (2010). A taxonomy of interdisciplinarity. In R. Frodeman, J.T. Klein, and C. Mitcham (Eds.), The Oxford Handbook of Interdisciplinarity (pp. 15-30). Oxford, U.K.: Oxford University Press.

Kouzes, J.M., \& Posner, B.Z. (1995). The leadership challenge: How to get extraordinary things done in organizations. San Francisco: Jossey-Bass.

Lakhani, J., Benzies, K., \& Hayden, K.A. (2012). Attributes of interdisciplinary research teams: A comprehensive review of the literature. Clinical \& Investigative Medicine, 35(5), 260-265.

Landry, R., Traore, N., \& Godin, B. (1996). An econometric analysis of the effect of collaboration on academic research productivity. Higher Education, 32, 283-301. doi: 10.1007/BF00138868 


\section{Running Head: PI LEADERSHIP STYLE AND COLLABORATION}

Leonardi, P. (2013,June). Ambient awareness: Using social media to develop accurate organizational meta-knowledge. Paper presented at the Science of Team Science Conference, Chicago, IL.

Lucas, C. (1994). American higher education: A history. New York: St. Martin's Griffin.

Mannix, E., \& Neale, M.A. (2005). What differences make a difference? The promise and reality of diverse teams in organizations. Psychological Science in the Public Interest, 6(2): 31-55. doi: 10.1111/j.1529-1006.2005.00022.x

Masse, L.C., Moser, R.P., Stokols, D., Taylor, B.K., Marcus, S.E., Morgan, G.D., Hall, K.L., Croyle, R.T., \& Trochim, W.M. (2008). Measuring Collaboration and Transdisciplinary Integration in Team Science. American Journal of Preventive Medicine, 35 (S2), 151-160. doi: 10.1016/j.amepre.2008.05.020

Mathis, S. G. (1999). The relationship of leadership frame use of departmental chairs to faculty job satisfaction as perceived by selected departmental faculty members (Doctoral dissertation, West Virginia University, Morgantown, WV). Retrieved from http://etd.wvu.edu.

Minnis, M., John-Steiner, V., \& Weber, R.J. (1998). The challenge of studying collaboration. American Educational Research Journal, 35, 4, 773-783. doi: 10.3102/00028312035004773

Mosser, N. R. (2000). A study of the relationship between the perceived leadership style of nursing chairpersons and the organizational climate of baccalaureate nursing programs. (Doctoral dissertation, West Virginia University, Morgantown, WV). Retrieved from http://etd.wvu.edu.

Myaskovsky, L., Unikel, E., \& Dew, M.A. (2005). Effects of gender diversity on performance and interpersonal behavior in small work groups. Sex Roles, 52(9-10): 645-57. doi: $10.1007 / \mathrm{s} 11199-005-3732-8$ 


\section{Running Head: PI LEADERSHIP STYLE AND COLLABORATION}

National Research Council. (1996). Doctorate recipients from United States universities. Washington, DC.: National Academy Press.

National Science Foundation. (2013). Women, minorities, and persons with disability in science and engineering. Division of Science Resource Statistics. Arlington, VA. Retrieved from http://www.nsf.gov/statistics/wmpd.

Neff, T.J., \& Citrin, J.M. (1999). Lessons from the top. New York: Doubleday.

Oandasan, I., Baker, R., Barker, K., Bosco, C., D'Amour, D., Jones, L., \& Way, D. (2006). Teamwork in healthcare: Promoting effective teamwork in healthcare in Canada-policy synthesis and recommendations. Ottawa, Canada: Canadian Health Services Research Foundation.

O’Connor, G.C., Rice, M.P., Peters, L., \& Veryzer, R.W. (2003). Managing interdisciplinary, longitudinal research teams: extending grounded theory-building methodologies. Organizational Science, 14, 353-373.

Pelled, L.H. (1996). Demographic diversity, conflict, and work group outcomes: An intervening process theory. Organization Science, 7(6): 615-631. Retrieved from http://www.jstor.org/stable/2635051

Peters, T.J., \& Austin, N.K. (1985). A passion for excellence: The leadership difference. New York: Warner Books.

Peters, T.J., \& Waterman, R.H. (1982). In search of excellence. New York: Harper \& Row.

Petersen, A.M., Riccaboni, M., Stanley, H.E., \& Pammoli, F. (2012). Persistence and uncertainty in the academic career. Proceedings of the National Academy of Sciences of the United States of America, 109(143), 5213-5218. doi: 10.1073/pnas.1121429109

Pohl, C. (2013, June). Sustainability and transdisciplinary research. Paper presented at the Science of Team Science Conference, Chicago, IL. 


\section{Running Head: PI LEADERSHIP STYLE AND COLLABORATION}

Rosenfield, P.L. (1992). The potential of transdisciplinary research for sustaining and extending linkages between the health and social sciences. Social Science Medicine, 35, 1343-1357. doi: 10.1016/0277-9536(92)90038-R

Rosenfield, P.L. (2013, June). The sustainability of team science: A decade of health and social science teams - what do we know and what do we need to know. Paper presented at the Science of Team Science Conference, Chicago, IL.

Rubin, E.R., \& Black, C.E. (2005). Organization, management, and research in academic health science centers. Washington, DC: Association of Academic Health Science Centers.

Russell, J.F. \& Flynn, R.B. (2000). Commonalities across effective collaboratives. Peabody Journal of Education, 75, 196-204. doi: 10.1207/S15327930PJE7503_13

Schnell, J. (2013, June). Bibliometric and network indicators of performance in cross-sector teams. Paper presented at the Science of Team Science Conference, Chicago, IL.

Siegel, D.S., Waldman, D.A., Atwater, L.E., \& Link, A.N. (2003). Commercial knowledge transfers from universities to firms: Improving the effectiveness of university-industry collaboration. Journal of High Technology Management Research, 14(1), 111-133. doi: 10.1016/S1047$8310(03) 00007-5$

Small, T. T. (2002). A study of the relationship between the perceived leadership style of nursing chairpersons and the organizational effectiveness of baccalaureate 179 nursing programs. (Doctoral dissertation, West Virginia University, Morgantown, WV). Retrieved from http://etd.wvu.edu/templates/showETD.cfm?recnum=2424.

Smedley, B.D., \& Syme, S.L. (Eds.). (2000). Promoting health: Intervention strategies from social and behavioral research. Washington, DC: National Academy Press. 
Running Head: PI LEADERSHIP STYLE AND COLLABORATION

Spring, B., Moller, A.C., \& Falk-Krzesinski, H.J. (2011). Team science.net. Northwestern University. Retrieved from http://www.teamscience.net.

Stokols, D., Hall, K.L., Taylor, B.K., \& Moser, R.P. (2008). The science of team science: Overview of the field and introduction to the supplement. American Journal of Preventive Medicine, 35(S2), 77-89. doi: 10.1016/j.amepre.2008.05.002

Stogdill, R.M. (1948). Personal factors associated with leadership: A survey of the literature. Journal of Psychology, 25, 35-71. doi: 10.1080/00223980.1948.9917362

Tierney, W.C. (2006). Trust and the public good. New York: Peter Lang Publishing.

Tobin, K. (2007). Collective responsibilities for research in science education - The tenure process. Cultural Studies of Science Education, 1(3), 417-421. doi: 10.1007/s11422-0069025-x

Turley, C.L. (2002). Radiation therapy program directors: A frame analysis of leadership in higher education (Doctoral dissertation). Retrieved from Proquest, UMI Dissertations Publishing. 3045492.

Wartman, S.A. (2007). 2007 Annual Report. Washington, DC: Association of Academic Health Centers.

Webber, S.S., \& Donahue, L.M. (2001). Impact of highly and less job-related diversity on work group cohesion and performance: A meta-analysis. Journal of Management, 27, 141-162. doi: $10.1177 / 014920630102700202$

White, R., \& Lippett, R. (1968). Group dynamics ( $3^{\text {rd }}$ ed.). New York: Harper \& Row.

Wood, D.J., \& Gray, B. (1991). Toward a comprehensive theory of collaboration. Journal of Applied Behavioral Science, 27(2), 139-162. doi: 10.1177/0021886391272001

Woolley, A.W., Chabris, C. F., Pentland, A., Hashmi, N., \& Malone, T.W. (2010). Evidence for a collaborative intelligence factor in the performance of human groups. Science, 330: 686-688. 
Running Head: PI LEADERSHIP STYLE AND COLLABORATION

doi: 10.1126/science. 1193147

Wuchty, S., Jones, B.F., \& Uzzi, B. (2007). The increasing dominance in teams in production of knowledge. Science, 316, 1036-1038. doi: 10.1126/science.1136099

Yukl, G. A. (1998). Leadership in organizations (4th ed.). Upper Saddle River, NJ:

Prentice Hall.

Yukl, G.A. (2002). Leadership in organizations (5 ${ }^{\text {th }}$ ed.). Upper Saddle River, NJ: Prentice Hall. 


\section{Running Head: PI LEADERSHIP STYLE AND COLLABORATION}

\section{Appendix A}

\section{Permission to Use Table of Factors Facilitating and Constraining Transdisciplinary}

\section{Science}

\section{Kennedy, Stephenie}

$\begin{array}{ll}\text { From: } & \text { Pat Rosenfield <plin56009gmail.coms } \\ \text { Sent: } & \text { Friday, July 12, 2013 11:52 AM } \\ \text { To: } & \text { Frank Kesseb Kennedy, Stephenie } \\ \text { Subject: } & \text { Re: Permission }\end{array}$

Dear Stephanie,

You have my permission, too. It would be great to see any papers you write from your ressearch.

Happy finishing!

Patricia Rosenfield

p.s. Just fyi- I chair the board of an NGO based in Franklin, WV. It is heavenly country, for sure. PR

On Fri, Jul 12, 2013 at 11:40 AM, Frank Kessel <kesfam@pdq, net- wrote:

EXCELLENT, Stephanie. You certainly have my permission to use that table. You should, however, also get. permission from my co-author, Patricia Rosenfield. So I'm Cc'ing her on this.

Best of luck on the thesis. And please do let us know how your research unfolds!

Frank Kessel

On Jul 12, 2013, at 9:22 AM, Kennedy, Stephenie wrote:

Dr, Kessel,

Thanks so much for your response. The delay has not affected my time line as I am awaiting committee feedback on my final chapter. I am cleaning the document and preparing for the defense and very much anticipating the end of this process.

1 appreciate your willingness to grant permission for use of the table. I am referring to the table entitled "Factors facilitating and constraining transdisciplinary science ${ }^{*}$ as it appeared in the following reference:

Kessel, F., \& Rosenfield, P.L. (2008), Toward transdisciplinary research historical and contemporary

perspectives. American Journal of Preventive Medicine, 35 (S2), 225-234.

Thanks.

Stephenie

Stephenie K. Kennedy

Cancer Prevention and Control

Mary Babb Randolph Cancer Center 


\section{Running Head: PI LEADERSHIP STYLE AND COLLABORATION}

\section{Appendix B}

Permission to Use Hersey and Blanchard's Four Quadrant Model of Situational Leadership

Kennedy, Stephenie

From:

Sent:

Brandy Archambeault [brandy.archambeault@situational.com]

To:

Monday, July 19, 2010 4:57 PM

Subject:

Kennedy. Stephenie

Attachments:

image001.jpg: image003.jpg; image004.png

Dear Stephanie

i am writing on behalf of the Center for Leadership Studies regarding a request for permission to use our copyrighted material in the following project:

$\begin{array}{ll}\text { Title: } & \text { Literature review section of a student dissertation } \\ \text { Author (5):- } & \text { Stephanie Kennedy } \\ \text { Est. Pub Date- } & 2010 / 2011\end{array}$

At this time, permission to reproduce the 2006 copyrighted version of the Situational Leadershipl model (Addendum A) has been approved sans Permissions Fee. To recap, you have agreed to use with the credit line: $\odot$ Copyright 2006 Reprinted with permission of the Center for Leadership Studies. Escondido, CA 92025. wuw. situational:com All Rights Reserved.

Permission is granted for this current edition of your work only. All references to Situational Leadershipe therein must be capitalized and have the $\odot$ follow whenever it appears. Our material may not be used in derivative works. Nonexclusive rights to publish or reproduce in printed text in North America have been granted. No world rights have been granted - this means you may print only in English (no translations) and only in North America with no further restrictions intended on our part regarding the sale or distribution of your work throughout the world. None of our copyrighted material may be made available electronically.

I hereby represent and warrant that I have the right to grant permission to use the material specified above without violation of third party rights.

\section{Brandy Archambeault}

Copyrient and Permissions officer

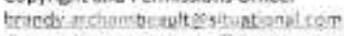

direct $760755-1464 \cdot$ office $800330-2840 \cdot \operatorname{tax} 760755-1247$



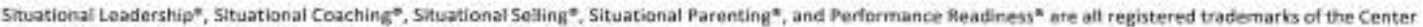
for Leadership Studios $\bullet 230$ West Third Avenue * Escondide, CA $92025 \cdot$ wow situaboral,forl

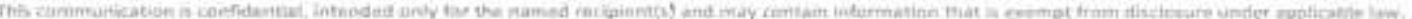



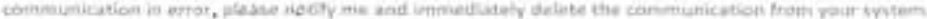

Addendum A 


\section{Appendix $C$}

Carnegie Classification: Research Universities (very high research activity)

\begin{tabular}{|c|c|c|}
\hline Institution & Location & Control \\
\hline Arizona State University & Tempe, Arizona & Public \\
\hline Boston University & Boston, Massachusetts & $\begin{array}{l}\text { Private not-for- } \\
\text { profit }\end{array}$ \\
\hline Brandeis University & Waltham, Massachusetts & $\begin{array}{l}\text { Private not-for- } \\
\text { profit }\end{array}$ \\
\hline Brown University & Providence, Rhode Island & $\begin{array}{l}\text { Private not-for- } \\
\text { profit }\end{array}$ \\
\hline California Institute of Technology & Pasadena, California & $\begin{array}{l}\text { Private not-for- } \\
\text { profit }\end{array}$ \\
\hline Carnegie Mellon University & Pittsburgh, Pennsylvania & $\begin{array}{l}\text { Private not-for- } \\
\text { profit }\end{array}$ \\
\hline Case Western Reserve University & Cleveland, Ohio & $\begin{array}{l}\text { Private not-for- } \\
\text { profit }\end{array}$ \\
\hline Colorado State University & Fort Collins, Colorado & Public \\
\hline Columbia University in the City of New York & New York, New York & $\begin{array}{l}\text { Private not-for- } \\
\text { profit }\end{array}$ \\
\hline Cornell University & Ithaca, New York & $\begin{array}{l}\text { Private not-for- } \\
\text { profit }\end{array}$ \\
\hline CUNY Graduate School and University Center & New York, New York & Public \\
\hline Dartmouth College & Hanover, New Hampshire & $\begin{array}{l}\text { Private not-for- } \\
\text { profit }\end{array}$ \\
\hline Duke University & Durham, North Carolina & $\begin{array}{l}\text { Private not-for- } \\
\text { profit }\end{array}$ \\
\hline Emory University & Atlanta, Georgia & $\begin{array}{l}\text { Private not-for- } \\
\text { profit }\end{array}$ \\
\hline Florida State University & Tallahassee, Florida & Public \\
\hline George Washington University & $\begin{array}{l}\text { Washington, District of } \\
\text { Columbia }\end{array}$ & $\begin{array}{l}\text { Private not-for- } \\
\text { profit }\end{array}$ \\
\hline Georgetown University & $\begin{array}{l}\text { Washington, District of } \\
\text { Columbia }\end{array}$ & $\begin{array}{l}\text { Private not-for- } \\
\text { profit }\end{array}$ \\
\hline Georgia Institute of Technology-Main Campus & Atlanta, Georgia & Public \\
\hline Georgia State University & Atlanta, Georgia & Public \\
\hline Harvard University & Cambridge, Massachusetts & $\begin{array}{l}\text { Private not-for- } \\
\text { profit }\end{array}$ \\
\hline Indiana University-Bloomington & Bloomington, Indiana & Public \\
\hline lowa State University & Ames, lowa & Public \\
\hline Johns Hopkins University & Baltimore, Maryland & $\begin{array}{l}\text { Private not-for- } \\
\text { profit }\end{array}$ \\
\hline $\begin{array}{l}\text { Louisiana State University and Agricultural \& } \\
\text { Mechanical College }\end{array}$ & Baton Rouge, Louisiana & Public \\
\hline Massachusetts Institute of Technology & Cambridge, Massachusetts & $\begin{array}{l}\text { Private not-for- } \\
\text { profit }\end{array}$ \\
\hline Michigan State University & East Lansing, Michigan & Public \\
\hline Mississippi State University & Mississippi State, Mississippi & Public \\
\hline Montana State University & Bozeman, Montana & Public \\
\hline New York University & New York, New York & $\begin{array}{l}\text { Private not-for- } \\
\text { profit }\end{array}$ \\
\hline
\end{tabular}




\begin{tabular}{|c|c|c|}
\hline North Carolina State University at Raleigh & Raleigh, North Carolina & Public \\
\hline North Dakota State University-Main Campus & Fargo, North Dakota & Public \\
\hline Northwestern University & Evanston, Illinois & $\begin{array}{l}\text { Private not-for- } \\
\text { profit }\end{array}$ \\
\hline Ohio State University-Main Campus & Columbus, Ohio & Public \\
\hline Oregon State University & Corvallis, Oregon & Public \\
\hline Pennsylvania State University-Main Campus & $\begin{array}{l}\text { University Park, } \\
\text { Pennsylvania }\end{array}$ & Public \\
\hline Princeton University & Princeton, New Jersey & $\begin{array}{l}\text { Private not-for- } \\
\text { profit }\end{array}$ \\
\hline Purdue University-Main Campus & West Lafayette, Indiana & Public \\
\hline Rensselaer Polytechnic Institute & Troy, New York & $\begin{array}{l}\text { Private not-for- } \\
\text { profit }\end{array}$ \\
\hline Rice University & Houston, Texas & $\begin{array}{l}\text { Private not-for- } \\
\text { profit }\end{array}$ \\
\hline Rockefeller University & New York, New York & $\begin{array}{l}\text { Private not-for- } \\
\text { profit }\end{array}$ \\
\hline Rutgers University-New Brunswick & New Brunswick, New Jersey & Public \\
\hline Stanford University & Stanford, California & $\begin{array}{l}\text { Private not-for- } \\
\text { profit }\end{array}$ \\
\hline Stony Brook University & Stony Brook, New York & Public \\
\hline SUNY at Albany & Albany, New York & Public \\
\hline Texas A \& M University & College Station, Texas & Public \\
\hline The University of Tennessee & Knoxville, Tennessee & Public \\
\hline The University of Texas at Austin & Austin, Texas & Public \\
\hline Tufts University & Medford, Massachusetts & $\begin{array}{l}\text { Private not-for- } \\
\text { profit }\end{array}$ \\
\hline Tulane University of Louisiana & New Orleans, Louisiana & $\begin{array}{l}\text { Private not-for- } \\
\text { profit }\end{array}$ \\
\hline University at Buffalo & Buffalo, New York & Public \\
\hline University of Alabama at Birmingham & Birmingham, Alabama & Public \\
\hline University of Alabama in Huntsville & Huntsville, Alabama & Public \\
\hline University of Arizona & Tucson, Arizona & Public \\
\hline University of Arkansas & Fayetteville, Arkansas & Public \\
\hline University of California-Berkeley & Berkeley, California & Public \\
\hline University of California-Davis & Davis, California & Public \\
\hline University of California-Irvine & Irvine, California & Public \\
\hline University of California-Los Angeles & Los Angeles, California & Public \\
\hline University of California-Riverside & Riverside, California & Public \\
\hline University of California-San Diego & La Jolla, California & Public \\
\hline University of California-Santa Barbara & Santa Barbara, California & Public \\
\hline University of California-Santa Cruz & Santa Cruz, California & Public \\
\hline University of Central Florida & Orlando, Florida & Public \\
\hline University of Chicago & Chicago, Illinois & $\begin{array}{l}\text { Private not-for- } \\
\text { profit }\end{array}$ \\
\hline University of Cincinnati-Main Campus & Cincinnati, Ohio & Public \\
\hline University of Colorado at Boulder & Boulder, Colorado & Public \\
\hline University of Connecticut & Storrs, Connecticut & Public \\
\hline University of Delaware & Newark, Delaware & Public \\
\hline University of Florida & Gainesville, Florida & Public \\
\hline University of Georgia & Athens, Georgia & Public \\
\hline University of Hawaii at Manoa & Honolulu, Hawaii & Public \\
\hline University of Houston & Houston, Texas & Public \\
\hline University of Illinois at Chicago & Chicago, Illinois & Public \\
\hline University of Illinois at Urbana-Champaign & Champaign, Illinois & Public \\
\hline
\end{tabular}




\begin{tabular}{|c|c|c|}
\hline University of lowa & lowa City, lowa & Public \\
\hline University of Kansas & Lawrence, Kansas & Public \\
\hline University of Kentucky & Lexington, Kentucky & Public \\
\hline University of Louisville & Louisville, Kentucky & Public \\
\hline University of Maryland-College Park & College Park, Maryland & Public \\
\hline University of Massachusetts Amherst & Amherst, Massachusetts & Public \\
\hline University of Miami & Coral Gables, Florida & $\begin{array}{l}\text { Private not-for- } \\
\text { profit }\end{array}$ \\
\hline University of Michigan-Ann Arbor & Ann Arbor, Michigan & Public \\
\hline University of Minnesota-Twin Cities & Minneapolis, Minnesota & Public \\
\hline University of Missouri-Columbia & Columbia, Missouri & Public \\
\hline University of Nebraska-Lincoln & Lincoln, Nebraska & Public \\
\hline University of New Mexico-Main Campus & Albuquerque, New Mexico & Public \\
\hline University of North Carolina at Chapel Hill & Chapel Hill, North Carolina & Public \\
\hline University of Notre Dame & Notre Dame, Indiana & $\begin{array}{l}\text { Private not-for- } \\
\text { profit }\end{array}$ \\
\hline University of Oklahoma Norman Campus & Norman, Oklahoma & Public \\
\hline University of Oregon & Eugene, Oregon & Public \\
\hline University of Pennsylvania & Philadelphia, Pennsylvania & $\begin{array}{l}\text { Private not-for- } \\
\text { profit }\end{array}$ \\
\hline University of Pittsburgh-Pittsburgh Campus & Pittsburgh, Pennsylvania & Public \\
\hline University of Rochester & Rochester, New York & $\begin{array}{l}\text { Private not-for- } \\
\text { profit }\end{array}$ \\
\hline University of South Carolina-Columbia & Columbia, South Carolina & Public \\
\hline University of South Florida-Tampa & Tampa, Florida & Public \\
\hline University of Southern California & Los Angeles, California & $\begin{array}{l}\text { Private not-for- } \\
\text { profit }\end{array}$ \\
\hline University of Utah & Salt Lake City, Utah & Public \\
\hline University of Virginia-Main Campus & Charlottesville, Virginia & Public \\
\hline University of Washington-Seattle Campus & Seattle, Washington & Public \\
\hline University of Wisconsin-Madison & Madison, Wisconsin & Public \\
\hline Vanderbilt University & Nashville, Tennessee & $\begin{array}{l}\text { Private not-for- } \\
\text { profit }\end{array}$ \\
\hline Virginia Commonwealth University & Richmond, Virginia & Public \\
\hline Virginia Polytechnic Institute and State University & Blacksburg, Virginia & Public \\
\hline Washington State University & Pullman, Washington & Public \\
\hline Washington University in St Louis & Saint Louis, Missouri & $\begin{array}{l}\text { Private not-for- } \\
\text { profit }\end{array}$ \\
\hline Wayne State University & Detroit, Michigan & Public \\
\hline Yale University & New Haven, Connecticut & $\begin{array}{l}\text { Private not-for- } \\
\text { profit }\end{array}$ \\
\hline Yeshiva University & New York, New York & $\begin{array}{l}\text { Private not-for- } \\
\text { profit }\end{array}$ \\
\hline
\end{tabular}


Appendix D

Initial Institutional Scripts

1. Script for contacting institutions to identify their funded projects and PI contact information:

My name is Stephenie Kennedy and I am conducting a research project as part of the degree requirements for a doctorate in Educational Leadership at WVU. I am interested in surveying research team members from your Health Sciences Center and need to know the best method for securing the names of funded projects and the Principal Investigators leading these projects. Can you identify a contact person best suited from your institution to assist with this process?

*This script will be repeated with the contact person so that the projects and names can be obtained.

\section{Email to Principal Investigators}

My name is Stephenie Kennedy and I am interested in surveying research team members from interdisciplinary teams at health sciences centers. Your institution has identified your project entitled (fill in the blank) for potential inclusion. Please click on the link below to answer four brief questions that will take five minutes or less. I appreciate your willingness to help me identify interdisciplinary team members; your cooperation will help me complete my dissertation and I cannot thank you enough for assisting me.

This research is being conducted as part of the degree requirements for a doctorate in Educational Leadership at WVU under the supervision of Dr. Reagan Curtis, an associate professor in the College of Human Resources and Education. 


\title{
Appendix E
}

\author{
Introductory Email
}

\section{Dear Participant,}

This e-mail is a request for you to take part in a research project to assess your experience as a member of an interdisciplinary research team. This project is being conducted by Stephenie Kennedy, MA as part of the degree requirements for a doctorate in Educational Leadership at WVU under the supervision of Dr. Reagan Curtis, an associate professor in the College of Human Resources and Education. Your participation in this project is greatly appreciated and will take approximately 20 minutes to fill out the attached questionnaire.

Your involvement in this project will be kept as confidential as legally possible. All data will be reported in the aggregate. You must be 18 years of age or older to participate. I will not ask any information that should lead back to your identity as a participant. Your participation is completely voluntary. You may skip any question that you do not wish to answer and you may discontinue at any time. West Virginia University's Institutional Review Board acknowledgement of this project is on file. At the end of the survey you have the option of entering a drawing for a \$100 Visa gift card, which I am raffling off as a token of my appreciation for your participation. To enter the drawing, you will need to provide me with your name, phone number, and e-mail address at the end of the survey. This information will not be stored with the answers to your survey.

I hope that you will participate in this research project, as it could be beneficial in understanding the impact of the leadership style of principal investigators on the collaboration satisfaction of research team members. Thank you very much for your time. Should you have any questions about this e-mail or the research project, please feel free to contact Stephenie Kennedy at (304) 293-0489 or by e-mail at skennedy@ hsc.wvu.edu or Reagan Curtis at (304) 293-2098 or by email at Reagan.Curtis@mail.wvu.edu.

If you choose to participate, your ID Number is (this will be assigned once the team identification forms are received from the PIs). All you have to do is clink the link below (to be generated by the software when surveys are ready to deploy, following IRB approval), type in your ID number, and answer the questions.

Thank you for your time and help with this project.

Sincerely, 
Stephenie K. Kennedy

\section{Appendix $F$}

\section{Team Identification Form}

This research project is being conducted by Stephenie Kennedy, MA as part of the degree requirements for a doctorate in Educational Leadership at WVU under the supervision of Dr. Reagan Curtis, an associate professor in the College of Human Resources and Education. Your participation is voluntary and the information provided will be used solely to solicit potential participants. Upon completion of data collection all Team Identification Forms will be destroyed. Your participation in this project is greatly appreciated and will take approximately 5 minutes to fill out the attached questionnaire.

Institution:

Project Name:

Principal Investigator:

For the purpose of this study the term interdisciplinary research team represents projects for which key personnel by virtue of their academic training bring expertise in more than two fields.

1. Based on this definition, do you identify the project listed above as interdisciplinary?

Yes _ No

2. If yes, please list the names of all research team members working on this project. Team members include co-investigators, professional staff, laboratory staff, students, and any others you deem as part of the team.

Team Member Name $\quad$ E-mail address

*If you are serving as the PI of more than one project you define as interdisciplinary, please identify the additional project name(s) and fill in the appropriate answers to questions 1 and 2.

Please identify any other information that you believe the researcher needs to know about your research project. 


\section{Appendix $G$}

\section{Demographic Questionnaire}

ID Number

Please check the most appropriate category for the following:

1. Your Gender: M

F

2. Your role on the research team: Co-investigator

Professional staff

Laboratory staff

Student

Other please indicate

3. Field in which you received your most advanced degree:

4. Where is your primary academic appointment:

School of Medicine

School of Nursing

School of Dentistry

School of Pharmacy

Other please indicate

5. Is your position $100 \%$ supported by one research project? Yes No

6. Gender of PI: M F

7. Size of research team: 
5 members or less , between 6 and 10 members , or 11 and greater

8. Number of years PI served as a PI (on this or other projects):

less than 3 years , 4 to 5 years , and longer than 6 years

\section{Appendix $H$}

\section{Leadership Orientations (Others)}

\section{Leadership Orientations Others}

This questionnaire asks you to describe the principal investigator in terms of leadership behavior. Please indicate how often each item is true of the person you are rating using the following scale: (1) never, (2) occasionally, (3) sometimes, (4) often, or (5) always. Circle the most appropriate response.

\begin{tabular}{|c|c|c|c|c|c|}
\hline & Never & Occasionally & Sometimes & Often & Always \\
\hline $\begin{array}{l}\text { Thinks very clearly and } \\
\text { logically }\end{array}$ & 1 & 2 & 3 & 4 & 5 \\
\hline $\begin{array}{l}\text { Shows high level of support } \\
\text { and concern for others }\end{array}$ & 1 & 2 & 3 & 4 & 5 \\
\hline $\begin{array}{l}\text { Shows exceptional ability } \\
\text { to mobilize people and } \\
\text { resources to get things } \\
\text { done }\end{array}$ & 1 & 2 & 3 & 4 & 5 \\
\hline $\begin{array}{l}\text { Inspires others to do their } \\
\text { best }\end{array}$ & 1 & 2 & 3 & 4 & 5 \\
\hline $\begin{array}{l}\text { Strongly emphasizes } \\
\text { careful planning and clear } \\
\text { time lines }\end{array}$ & 1 & 2 & 3 & 4 & 5 \\
\hline $\begin{array}{l}\text { Builds trust through open } \\
\text { and collaborative } \\
\text { relationships }\end{array}$ & 1 & 2 & 3 & 4 & 5 \\
\hline $\begin{array}{l}\text { Is a very skillful and } \\
\text { shrewd negotiator }\end{array}$ & 1 & 2 & 3 & 4 & 5 \\
\hline Is highly charismatic & 1 & 2 & 3 & 4 & 5 \\
\hline $\begin{array}{l}\text { Approaches problems } \\
\text { through logical analysis } \\
\text { and careful thinking }\end{array}$ & 1 & 2 & 3 & 4 & 5 \\
\hline $\begin{array}{l}\text { Shows high sensitivity and } \\
\text { concern for others' needs }\end{array}$ & 1 & 2 & 3 & 4 & 5 \\
\hline
\end{tabular}




\begin{tabular}{|c|c|c|c|c|c|}
\hline $\begin{array}{l}\text { Is unusually persuasive } \\
\text { and influential }\end{array}$ & 1 & 2 & 3 & 4 & 5 \\
\hline Is an inspiration to others & 1 & 2 & 3 & 4 & 5 \\
\hline $\begin{array}{l}\text { Develops and implements } \\
\text { clear, logical policies and } \\
\text { procedures }\end{array}$ & 1 & 2 & 3 & 4 & 5 \\
\hline $\begin{array}{l}\text { Fosters high levels of } \\
\text { participation and } \\
\text { involvement in decisions }\end{array}$ & 1 & 2 & 3 & 4 & 5 \\
\hline $\begin{array}{l}\text { Anticipates and deals } \\
\text { adroitly with } \\
\text { organizational conflict }\end{array}$ & 1 & 2 & 3 & 4 & 5 \\
\hline $\begin{array}{l}\text { Is highly imaginative and } \\
\text { creative }\end{array}$ & 1 & 2 & 3 & 4 & 5 \\
\hline $\begin{array}{l}\text { Approaches problems with } \\
\text { facts and logic }\end{array}$ & 1 & 2 & 3 & 4 & 5 \\
\hline $\begin{array}{l}\text { Is consistently helpful and } \\
\text { responsive to others }\end{array}$ & 1 & 2 & 3 & 4 & 5 \\
\hline $\begin{array}{l}\text { Is very effective in getting } \\
\text { support from people with } \\
\text { influence and power }\end{array}$ & 1 & 2 & 3 & 4 & 5 \\
\hline $\begin{array}{l}\text { Communicates a strong } \\
\text { and challenging vision and } \\
\text { sense of mission }\end{array}$ & 1 & 2 & 3 & 4 & 5 \\
\hline $\begin{array}{l}\text { Sets specific, measurable } \\
\text { goals and holds people } \\
\text { accountable for results }\end{array}$ & 1 & 2 & 3 & 4 & 5 \\
\hline $\begin{array}{l}\text { Listens well and is } \\
\text { unusually receptive to } \\
\text { other people's ideas and } \\
\text { input }\end{array}$ & 1 & 2 & 3 & 4 & 5 \\
\hline $\begin{array}{l}\text { Is politically very sensitive } \\
\text { and skillful }\end{array}$ & 1 & 2 & 3 & 4 & 5 \\
\hline $\begin{array}{l}\text { Sees beyond current } \\
\text { realities to create exciting } \\
\text { new opportunities }\end{array}$ & 1 & 2 & 3 & 4 & 5 \\
\hline
\end{tabular}


Running Head: PI LEADERSHIP STYLE AND COLLABORATION

\begin{tabular}{|c|c|c|c|c|c|}
\hline $\begin{array}{l}\text { Has extraordinary } \\
\text { attention to detail }\end{array}$ & 1 & 2 & 3 & 4 & 5 \\
\hline $\begin{array}{l}\text { Gives personal recognition } \\
\text { for work well done }\end{array}$ & 1 & 2 & 3 & 4 & 5 \\
\hline $\begin{array}{l}\text { Develops alliances to build } \\
\text { a strong base of support }\end{array}$ & 1 & 2 & 3 & 4 & 5 \\
\hline $\begin{array}{l}\text { Generates loyalty and } \\
\text { enthusiasm }\end{array}$ & 1 & 2 & 3 & 4 & 5 \\
\hline $\begin{array}{l}\text { Strongly believes in clear } \\
\text { structure and a chain of } \\
\text { command }\end{array}$ & 1 & 2 & 3 & 4 & 5 \\
\hline $\begin{array}{l}\text { Is a highly participative } \\
\text { manager }\end{array}$ & 1 & 2 & 3 & 4 & 5 \\
\hline $\begin{array}{l}\text { Succeeds in the face of } \\
\text { conflict and opposition }\end{array}$ & 1 & 2 & 3 & 4 & 5 \\
\hline $\begin{array}{l}\text { Serves as an influential } \\
\text { model of organizational } \\
\text { aspirations and values }\end{array}$ & 1 & 2 & 3 & 4 & 5 \\
\hline
\end{tabular}

Copyright 1990, Lee G. Bolman and Terence E. Deal 


\section{Appendix I}

\section{Collaboration and Transdisciplinary Integration Survey}

\section{Collaboration and Transdisciplinary Integration Survey}

Please evaluate the collaboration within your center by indicating if the collaboration is (1) inadequate, (2) poor, (3) satisfactory, (4) good, or (5) excellent. Circle the most appropriate response.

\begin{tabular}{|c|c|c|c|c|c|}
\hline & Inadequate & Poor & Satisfactory & $\overline{\text { Good }}$ & Excellent \\
\hline Acceptance of new ideas & 1 & 2 & 3 & 4 & 5 \\
\hline $\begin{array}{l}\text { Communication among } \\
\text { collaborators }\end{array}$ & 1 & 2 & 3 & 4 & 5 \\
\hline $\begin{array}{l}\text { Ability to capitalize on the } \\
\text { strengths of different } \\
\text { researchers }\end{array}$ & 1 & 2 & 3 & 4 & 5 \\
\hline $\begin{array}{l}\text { Organization or structure } \\
\text { of collaborative teams }\end{array}$ & 1 & 2 & 3 & 4 & 5 \\
\hline $\begin{array}{l}\text { Resolution of conflicts } \\
\text { among collaborators }\end{array}$ & 1 & 2 & 3 & 4 & 5 \\
\hline $\begin{array}{l}\text { Involvement of } \\
\text { collaborators from outside } \\
\text { the center }\end{array}$ & 1 & 2 & 3 & 4 & 5 \\
\hline $\begin{array}{l}\text { Involvement of } \\
\text { collaborators from diverse } \\
\text { disciplines }\end{array}$ & 1 & 2 & 3 & 4 & 5 \\
\hline $\begin{array}{l}\text { Productivity of } \\
\text { collaboration meetings }\end{array}$ & 1 & 2 & 3 & 4 & 5 \\
\hline $\begin{array}{l}\text { Overall productivity of } \\
\text { meetings }\end{array}$ & 1 & 2 & 3 & 4 & 5 \\
\hline $\begin{array}{l}\text { Productivity in developing } \\
\text { new products (e.g., papers, } \\
\text { proposals, courses) }\end{array}$ & 1 & 2 & 3 & 4 & 5 \\
\hline $\begin{array}{l}\text { Overall productivity of } \\
\text { collaboration }\end{array}$ & 1 & 2 & 3 & 4 & 5 \\
\hline
\end{tabular}


Please rate your views about collaboration with respect to your center-related research by indicating if you (1) strongly disagree, (2) somewhat disagree, (3) not sure, (4) somewhat agree, or (5) strongly agree with the statement. Circle the most appropriate response.

\begin{tabular}{|c|c|c|c|c|c|}
\hline & $\begin{array}{l}\text { Strongly } \\
\text { Disagree }\end{array}$ & $\begin{array}{l}\text { Somewhat } \\
\text { Disagree }\end{array}$ & Not Sure & $\begin{array}{l}\text { Somewhat } \\
\text { Agree }\end{array}$ & $\begin{array}{c}\text { Strongly } \\
\text { Agree }\end{array}$ \\
\hline $\begin{array}{l}\text { In general, collaboration } \\
\text { has improved your } \\
\text { research productivity }\end{array}$ & 1 & 2 & 3 & 4 & 5 \\
\hline $\begin{array}{l}\text { In general, collaboration } \\
\text { has improved the quality } \\
\text { of your research }\end{array}$ & 1 & 2 & 3 & 4 & 5 \\
\hline $\begin{array}{l}\text { Collaboration has posed a } \\
\text { significant time burden in } \\
\text { your research }\end{array}$ & 1 & 2 & 3 & 4 & 5 \\
\hline $\begin{array}{l}\text { You are comfortable } \\
\text { showing limits or gaps in } \\
\text { your knowledge to those } \\
\text { with whom you } \\
\text { collaborate }\end{array}$ & 1 & 2 & 3 & 4 & 5 \\
\hline $\begin{array}{l}\text { In general, you feel you } \\
\text { can trust the colleagues } \\
\text { with whom you } \\
\text { collaborate }\end{array}$ & 1 & 2 & 3 & 4 & 5 \\
\hline $\begin{array}{l}\text { In general, you find your } \\
\text { collaborators are open to } \\
\text { criticism }\end{array}$ & 1 & 2 & 3 & 4 & 5 \\
\hline $\begin{array}{l}\text { In general, you respect } \\
\text { your collaborators }\end{array}$ & 1 & 2 & 3 & 4 & 5 \\
\hline
\end{tabular}

Please rate the following attitudes about transdisciplinary research by indicating if you (1) strongly disagree, (2) somewhat disagree, (3) not sure, (4) somewhat agree, or (5) strongly agree with the statement. Circle the most appropriate response.

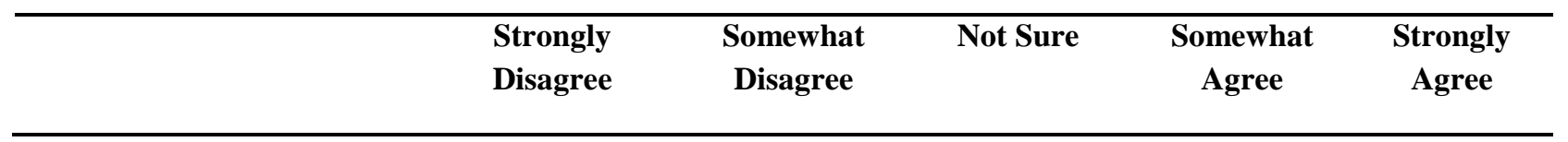




\begin{tabular}{lllll}
\hline $\begin{array}{l}\text { I would describe myself as } \\
\text { someone who strongly } \\
\text { values transdisciplinary } \\
\text { collaboration. }\end{array}$ & 1 & 2 & 4 & 5 \\
$\begin{array}{l}\text { Transdisciplinary } \\
\text { research interferes with } \\
\text { my ability to maintain } \\
\text { knowledge in my primary } \\
\text { area. }\end{array}$ & 1 & 2 & 3 & 4 \\
\end{tabular}

$\begin{aligned} & \text { I tend to be more } \\ & \text { productive working on my } \\ & \text { own rather than working } \\ & \text { as a member of a } \\ & \text { transdisciplinary research } \\ & \text { team. }\end{aligned}$
$\begin{aligned} & \text { In a transdisciplinary } \\ & \text { research group, it takes } \\ & \text { more time to produce a } \\ & \text { research article. }\end{aligned}$

\begin{tabular}{|c|c|c|c|c|c|}
\hline $\begin{array}{l}\text { Transdisciplinary } \\
\text { research stimulates me to } \\
\text { change my thinking. }\end{array}$ & 1 & 2 & 3 & 4 & 5 \\
\hline $\begin{array}{l}\text { I have changed the way I } \\
\text { pursue a research idea } \\
\text { because of my involvement } \\
\text { in transdisciplinary work. }\end{array}$ & 1 & 2 & 3 & 4 & 5 \\
\hline $\begin{array}{l}\text { Transdisciplinary } \\
\text { research has improved } \\
\text { how I conduct research. }\end{array}$ & 1 & 2 & 3 & 4 & 5 \\
\hline $\begin{array}{l}\text { I am optimistic that } \\
\text { transdisciplinary work } \\
\text { among participants will } \\
\text { lead to valuable scientific } \\
\text { outcomes that would not } \\
\text { have occurred without } \\
\text { collaboration. }\end{array}$ & 1 & 2 & 3 & 4 & 5 \\
\hline $\begin{array}{l}\text { Participating in a } \\
\text { transdisciplinary team } \\
\text { improves the interventions } \\
\text { that are developed. }\end{array}$ & 1 & 2 & 3 & 4 & 5 \\
\hline
\end{tabular}




Because of my
involvement in
transdisciplinary research,
I have an increased
understanding of what my
own discipline brings to
others.

$\begin{aligned} & \text { My transdisciplinary } \\ & \text { collaborations are } \\ & \text { sustainable over the long } \\ & \text { haul. }\end{aligned}$
$\begin{aligned} & \text { Generally speaking, I } \\ & \text { believe the benefits of } \\ & \text { transdisciplinary specific } \\ & \text { research outweigh the } \\ & \text { inconveniences and costs } \\ & \text { of such work. }\end{aligned}$

$\begin{aligned} & \text { I am comfortable working } \\ & \text { in a transdisciplinary } \\ & \text { environment. }\end{aligned}$
$\begin{aligned} & \text { Overall, I am pleased with } \\ & \text { the effort I have made to } \\ & \text { engage in } \\ & \text { transdisciplinary research. }\end{aligned}$

Members as a group are
open-minded about
considering research
perspectives from fields
other than their own.

From the Centre for Community Child Health Research, University of British Columbia (Masse), Vancouver, British Columbia, Canada; the Division of Cancer Control and Population Science (Moser, Marcus, Morgan, Hall, Croyle), National Cancer Institute, and the Office of Portfolio Analysis and Strategic Initiatives (Taylor), NIH, Bethesda, Maryland; the School of Social Ecology, University of California Irvine (Stokols), Irvine, California; and the Department of Policy Analysis and Management, Cornell University (Trochim), Ithaca, New York.

Address correspondence and reprint requests to: Louise C. Masse, PhD, University of British Columbia, Department of Pediatrics, Centre for Community Child Health Research, L408, 4480 Oak Street, Vancouver, British Columbia V6H 3V4, Canada. E-mail: Imasse@ cw.bc.ca. 
Running Head: PI LEADERSHIP STYLE AND COLLABORATION

\section{Appendix $J$}

Permission for Use of Leadership Orientations (Others) 


\section{Running Head: PI LEADERSHIP STYLE AND COLLABORATION}

Kennedy, Stephenie

$\begin{array}{ll}\text { From: } & \text { Lee Bolman [lee@leebolman.com] } \\ \text { Sent: } & \text { Friday, July 01, 2011 } 9: 57 \text { PM } \\ \text { To: } & \text { Kennedy, Stephenie } \\ \text { Subject: } & \text { Re: Instrument Use Request }\end{array}$

Dear Ms. Kennedy.

In response to your letter dated June 15, 2011, I am happy to give you permission to use the Leadership

Orientations survey in your doctoral work.

Best wishes in your research - 1 look forward to seeing the results of your study.

Lee G. Bolman, Ph.D.

Professor and Marion Bloch/Missouri Chair in Leadership

Bloch School of Management

University of Missouri-Kansas City

5100 Rockhill Road

Kansas City, MO 64110

Tel: 816-235-5407.

Website: www.leebolman.com

On Fri, 01 Jul 2011 15:16 -0400, "Kennedy, Stephenie" <skennedy@hsc.wvu.edu> wrote:

Dr, Bolman,

Please review the attached request and respond at your earliest convenience. I am also mailing a hard copy of the request. Thank you for your time and consideration.

Sincerely,

Stephenie

Stephenie K. Kennedy

Cancer Prevention and Control 
Running Head: PI LEADERSHIP STYLE AND COLLABORATION

Page 1 of 4

Stephenle Kennedy - RE: Measuring Collaboration

$\begin{array}{ll}\text { From: } & \text { "Masse, Louise" } \\ \text { To: } & \text { "Stephenie Kennedy" } \\ \text { Date: } & 10 / 6 / 2008 \text { 2:08 PM } \\ \text { Subject: } & \text { RE: Measuring Collaboration }\end{array}$

Stephenic, The instrument is included in the paper in Appendices A and B. You need to include the footnote to recreste the scale (see below). Please note that the items to include in the questionnaire should be taken from the article. As I know that this is probably an oider version what $I$ am including below. Louise

Permission to use the Collaboration and Transdisciplinary Integration Survey 